\title{
Protein aggregates nucleate ice: the example of apoferritin
}

\author{
María Cascajo-Castresana ${ }^{1,2,3}$, Robert O. David ${ }^{3,4}$, Maiara A. Iriarte-Alonso ${ }^{2}$, Alexander M. Bittner ${ }^{2,5}$, and \\ Claudia Marcolli ${ }^{3}$ \\ ${ }^{1}$ División de Salud, TECNALIA, Parque Tecnológico, Paseo de Mikeletegi, 2, 20009 Donostia, Spain \\ ${ }^{2}$ CIC nanoGUNE, Tolosa Hiribidea, 76, 20018 Donostia, Spain \\ ${ }^{3}$ Department of Environmental System Sciences, Institute for Atmospheric and Climate Science, \\ ETH Zurich, 8092 Zurich, Switzerland \\ ${ }^{4}$ Department of Geosciences, University of Oslo, Oslo, 0315, Norway \\ ${ }^{5}$ Ikerbasque, Basque Foundation for Science, Ma Díaz de Haro 3, 48013 Bilbao, Spain
}

Correspondence: Claudia Marcolli (claudia.marcolli@env.ethz.ch)

Received: 24 September 2019 - Discussion started: 7 October 2019

Revised: 10 February 2020 - Accepted: 17 February 2020 - Published: 20 March 2020

\begin{abstract}
Biological material has gained increasing attention recently as a source of ice-nucleating particles that may account for cloud glaciation at moderate supercooling. While the ice-nucleation (IN) ability of some bacteria can be related to membrane-bound proteins with epitaxial fit to ice, little is known about the IN-active entities present in biological material in general. To elucidate the potential of proteins and viruses to contribute to the IN activity of biological material, we performed bulk freezing experiments with the newly developed drop freezing assay DRoplet Ice Nuclei Counter Zurich (DRINCZ), which allows the simultaneous cooling of 96 sample aliquots in a chilled ethanol bath. We performed a screening of common proteins, namely the iron storage protein ferritin and its iron-free counterpart apoferritin, the milk protein casein, the egg protein ovalbumin, two hydrophobins, and a yeast ice-binding protein, all of which revealed IN activity with active site densities $>0.1 \mathrm{mg}^{-1}$ at $-10^{\circ} \mathrm{C}$. The tobacco mosaic virus, a plant virus based on helically assembled proteins, also proved to be IN active with active site densities increasing from $100 \mathrm{mg}^{-1}$ at $-14{ }^{\circ} \mathrm{C}$ to $10000 \mathrm{mg}^{-1}$ at $-20^{\circ} \mathrm{C}$. Among the screened proteins, the IN activity of horse spleen ferritin and apoferritin, which form cages of 24 co-assembled protein subunits, proved to be outstanding with active site densities $>10 \mathrm{mg}^{-1}$ at $-5^{\circ} \mathrm{C}$. Investigation of the $\mathrm{pH}$ dependence and heat resistance of the apoferritin sample confirmed the proteinaceous nature of its IN-active entities but excluded the correctly folded cage monomer as the IN-active species. A dilution series of apoferritin in water revealed two distinct freezing ranges, an upper one from
\end{abstract}

-4 to $-11^{\circ} \mathrm{C}$ and a lower one from -11 to $-21{ }^{\circ} \mathrm{C}$. Dynamic light scattering measurements related the upper freezing range to ice-nucleating sites residing on aggregates and the lower freezing range to sites located on misfolded cage monomers or oligomers. The sites proved to persist during several freeze-thaw cycles performed with the same sample aliquots. Based on these results, IN activity seems to be a common feature of diverse proteins, irrespective of their function, but arising only rarely, most probably through defective folding or aggregation to structures that are IN active.

\section{Introduction}

The formation and glaciation of mixed-phase clouds influence radiative transfer, and eventually initiate precipitation, thus determining cloud lifetime (DeMott et al., 2010; Mülmenstädt et al., 2015; Matus and l'Ecuyer, 2017; Kanji et al., 2017). Clouds may glaciate through the homogeneous freezing of cloud droplets when air masses cool below $-36^{\circ} \mathrm{C}$, or at a higher temperature in the presence of ice-nucleating particles (INPs). The characterization of INPs is a critical step towards understanding and predicting the climatic impacts of clouds (DeMott and Prenni, 2010).

When an INP is immersed in a cloud droplet, freezing occurs on the INP's surface through heterogeneous nucleation when the temperature falls below the threshold value for activation. This immersion freezing mechanism is considered to be the most common pathway to cloud glaciation (de Boer 
et al., 2010; Westbrook and Illingworth, 2013). Alternatively, cloud droplets may freeze while they come in contact with an INP (contact freezing) or while an INP activates to a cloud droplet (condensation freezing) (Murray et al., 2012; Vali et al., 2015; Kanji et al., 2017). After the formation of the first ice crystals, cloud glaciation may proceed through additional primary ice nucleation occurring on INPs that become active at lower temperatures, ice crystal multiplication (Hallett and Mossop, 1974; Yano and Phillips, 2011; Crawford et al., 2012; Lauber et al., 2018; Field et al., 2017), and the Wegener-Bergeron-Findeisen process (Wegener, 1911; Bergeron, 1928; Findeisen, 1938; Korolev, 2007; Korolev and Field, 2008).

INPs are a very small subgroup of atmospheric aerosol particles; they may represent just one in a million or even fewer particles of the whole aerosol population (DeMott et al., 2010). The best-established class of INPs are mineral dusts (Murray et al., 2012; Kanji et al., 2017), originating mainly from arid regions comprising the global dust belt which stretches from the Sahara to the Taklimakan (Sassen et al., 2003; Prospero et al., 2002; Ginoux et al., 2012; Engelstaedter et al., 2006). However, most mineral particles exhibit significant ice-nucleation (IN) activity only below $-15^{\circ} \mathrm{C}$ (Hoose and Möhler, 2012; Murray et al., 2012; Atkinson et al., 2013; Kanji et al., 2017). At higher temperatures, most atmospheric INPs that have been identified so far are of biological origin (Levin and Yankofsky, 1983; Murray et al., 2012; Kanji et al., 2017).

One source of biogenic INPs is soil organic matter containing plant litter, remains of micro-organisms, lipids, carbohydrates, peptides, cellulose, lignin, and humic substances (Simoneit et al., 2004; Oades, 1993; Conen et al., 2011; O'Sullivan et al., 2014; Hiranuma et al., 2015a; Rigg et al., 2013; Wang and Knopf, 2011). Soil dusts consisting of mineral particles mixed with a small fraction of soil organic matter have been shown to nucleate ice at a higher temperature than bare mineral dusts (Conen et al., 2011; O'Sullivan et al., 2014; Steinke et al., 2016; Knopf et al., 2018). Dust emanating from agricultural sources has been estimated to contribute around $20 \%$ to the global dust burden (O'Sullivan et al., 2014; Tegen et al., 2004; Zender et al., 2004). Recent studies suggest that perturbations of the soil and plant surfaces lead to the release of biological organisms that can serve as INPs (Huffman et al., 2013; Prenni et al., 2013; Tobo et al., 2013; DeMott et al., 2016). The biological origin of IN activity of soil dusts above $-15^{\circ} \mathrm{C}$ is usually inferred from the decrease in freezing temperature after heat treatment or digestion with hydrogen peroxide (Du et al., 2017; O'Sullivan et al., 2014; Hill et al., 2016).

The sea surface has also been examined as a source for biogenic INPs (Wilson et al., 2015; Ladino et al., 2016). Atmospheric INP concentrations measured on ships were found to be influenced by local marine biological activity and sea spray production (Bigg, 1973; Burrows et al., 2013). During a phytoplankton bloom, Wang et al. (2015) observed an in- crease in IN activity of sea spray aerosol above $-15^{\circ} \mathrm{C}$. Marine phytoplankton has been found to be IN active, in both intact cells and exudates (Schnell, 1975; Alpert et al., 2011; Wilson et al., 2015; Ladino et al., 2016).

Biological INPs include fungal spores; pollen; viruses; microorganisms like bacteria, algae, lichens, and archaea; and fragments, exudates, and excretions of microorganisms, plants, and animals (Murray et al., 2012, Morris et al., 2013a; Després et al., 2012; Kanji et al., 2017). Bacterial IN activity was found in Pseudomonas and related species like Xanthomonadaceae (Kim et al., 1987) and Enterobacteriaceae (Lindow et al., 1978) but rarely outside the Gammaproteobacteria (Ponder et al., 2005; Mortazavi et al., 2008; Failor et al., 2017). Pseudomonas syringae ( $P$. syringae) are the best-investigated IN-active bacteria. They have been isolated from decaying leaf litter and can induce freezing at temperatures up to $-2^{\circ} \mathrm{C}$ (Schnell and Vali, 1972; Maki et al., 1974; Vali et al., 1976; Möhler et al., 2007). P. syringae are gramnegative bacteria that populate leaf surfaces and are able to cause frost injuries in plants (Lindow, 1983; Hirano and Upper, 2000; Akila et al., 2018). They were shown to owe their IN activity to a protein located on the outer cell membrane that templates ice through a sequence of amino acids providing an epitaxial fit to ice (Kajava and Lindow, 1993; Murray et al., 2012). IN activity is preserved when the cells are disrupted, though with a shift to lower freezing temperatures (Govindarajan and Lindow, 1988). At lower temperatures, other types of bacteria (including gram-positive ones) also proved to exhibit IN activity (Ponder et al., 2005; Mortazavi et al., 2008; Failor et al., 2017; Akila et al., 2018).

Screening experiments revealed IN activity of lichen samples from a variety of locations with freezing onset temperatures up to $-5^{\circ} \mathrm{C}$ (Moffett et al., 2015), and even up to $-2.3^{\circ} \mathrm{C}$ (Kieft, 1988). The IN activity was found to originate primarily from the mycobiont (Kieft and Ahmadjian, 1989), providing evidence for a fungal rather than bacterial source of IN activity (Kieft and Ruscetti, 1990). The sites seem to be proteinaceous, although they are less sensitive to heat and $\mathrm{pH}$ variation compared with the ice-nucleating proteins expressed by P. syringae (Kieft and Ahmadjian, 1989; Kieft and Ruscetti, 1990, 1992). In screening experiments, most fungi failed to show IN activity above $-20^{\circ} \mathrm{C}$ with a few exceptions such as Fusarium acuminatum and Fusarium avenaceum (Pouleur et al., 1992; Pummer et al., 2013; Haga et al., 2013, 2014). Yet, IN-active fungi with freezing onsets as high as $-5^{\circ} \mathrm{C}$ could be identified in bioaerosols (Huffman et al., 2013) and in soils (Fröhlich-Nowoisky et al., 2015). Heat resistance and insensitivity to $\mathrm{pH}$ variation suggest that the IN-active entity is more similar to that of lichen than to that of bacteria (Pouleur et al., 1992). Surveys of the IN ability of pollen showed that only a few types were active, the most active ones stemming from birch and conifer trees, yet, only at temperatures below $-9^{\circ} \mathrm{C}$ (Diehl et al., 2001; von Blohn et al., 2005; Pummer et al., 2012). Intriguingly, water which has been in contact with pollen and then been sepa- 
rated nucleated ice as efficiently as the whole pollen grains themselves. Moreover, IN activity has also been found in aqueous extracts of birch leaves and branches (Felgitsch et al., 2018).

Heterogeneous ice nucleation is considered to arise from the ability of surfaces to order water molecules in an icelike pattern. The arrangement of water molecules at a surface depends on surface charge and functional groups (Glatz and Sarupria, 2016; Abdelmonem et al., 2017; Pummer et al., 2015). A relevant role is attributed to surface $\mathrm{OH}$ and $\mathrm{NH}$ groups that are able to form hydrogen bonds to water molecules. Their number and arrangement have been used to explain IN activity of different mineral surfaces (Pedevilla et al., 2007; Hu and Michaelides, 2007; Glatz and Sarupria, 2018; Kumar et al., 2019b). A lattice match between ice and the ice-nucleating agent is often considered a prerequisite for heterogeneous ice nucleation. Yet, while some IN-active substances such as AgI (Marcolli et al., 2016) and 2D-crystalline films formed by long-chain alcohols (Popovitz-Biro et al., 1994; Zobrist et al., 2007; Qiu et al., 2017) exhibit a lattice match, others such as quartz (Kumar et al., 2019a) do not, and even others such as $\mathrm{BaF}_{2}$ exhibit a lattice match but fail to be IN active (Conrad et al., 2005). The difficulty to pinpoint surface properties that are required for heterogeneous ice nucleation may be explained by growing evidence that it is not the whole surface that is able to nucleate ice but just special nucleation sites (Vali, 2014; Vali et al., 2015), which may arise through defects or impurities. Applying classical nucleation theory to heterogeneous ice nucleation yields nucleation site areas in the range of $10-50 \mathrm{~nm}^{2}$ required to host an ice embryo of critical size (Kaufmann et al., 2017).

Taking surfaces that are large enough to host a critical ice embryo and have the ability to form hydrogen bonds to water molecules as requirements for IN activity, organic molecules with hydroxyl or carboxyl functionalities should potentially be able to induce freezing (Pummer et al., 2015). Indeed, microcrystalline cellulose has been found to nucleate ice up to $-9^{\circ} \mathrm{C}$ (Hiranuma et al., 2015a). The IN activity of birch tree extracts stems from macromolecules or aggregates of macromolecules which involve polysaccharides (Pummer et al., 2012) and proteins (Tong et al., 2015; Felgitsch et al., 2018) that may coaggregate. Similarly, the exudate material acting as INPs in marine aerosol (Wilson et al., 2015; Ladino et al., 2016) was found to contain polysaccharidic and proteinaceous compounds (Aller et al., 2017). Finally, ice-nucleating proteins expressed by Pseudomonas exhibit a repetition unit containing threonine amino acids with hydroxyl functional groups that are able to template ice. Aggregates involving only a few of these proteins are water soluble and induce ice nucleation up to $-7^{\circ} \mathrm{C}$. Larger aggregates nucleate ice up to $-2{ }^{\circ} \mathrm{C}$ but require the intact outer cell membrane to be stable (Polen et al., 2016; Zachariassen and Kristiansen, 2000).

So far, investigations have been focused on proteins that are expressed by organisms to nucleate ice. Here we examine whether proteins as a type of macromolecule have an inherent ability to nucleate ice.

To elucidate the potential of proteins and viruses to contribute to the IN activity of biological material, we employed DRINCZ, a newly developed drop freezing assay (David et al., 2019), to screen the IN activity of common proteins, namely the iron storage protein ferritin and its ironfree counterpart apoferritin (with protein subunits assembled to a cage), the milk protein casein (in solution producing assembled casein micelles), the egg protein ovalbumin, the hydrophobins HPA and HPB, and the ice-binding protein LeIBP, produced by the yeast Leucosporidium. In addition, we also investigated the IN activity of the tobacco mosaic virus (TMV), a common plant virus, present in plants all over the world. Fillhart et al. (1997) showed that the nearly identical tomato mosaic Tobamovirus (ToMV) can be spread by fog (Fillhart et al., 1997). While all of the proteins and the virus exhibited IN activity, ferritin and apoferritin proved to be outstanding with freezing onsets as high as $-4^{\circ} \mathrm{C}$. Therefore, we focused in the following on the elucidation of the origin of the IN activity of ferritin and apoferritin samples.

\section{Material and methods}

\subsection{Description of the proteins and the virus}

\subsubsection{Ferritin and apoferritin}

Ferritin is composed of 24 (protein) subunits, which coassemble into a protein shell with an inner cavity of about $7-8 \mathrm{~nm}$ in diameter, hosting up to 4500 iron atoms $\left(\mathrm{Fe}^{3+}\right)$ in the form of an amorphous oxide, and an outer diameter of around $12 \mathrm{~nm}$ (see Fig. 1 for its structure). In bacteria and plants, ferritin is formed by 24 identical subunits assembled into a 432-point symmetric hollow shell (Aumiller Jr. et al., 2018; Ghirlando et al., 2016; Zeth et al., 2016). In mammals, the apoferritin cage is composed of L (light) and $\mathrm{H}$ (heavy) subunits, in a tissue-specific stoichiometry. The L-type subunit $(M \approx 20 \mathrm{kDa})$ is enriched in ferritin isolated from liver and spleen and contains a mineral nucleation site, while the H-type subunit $(M \approx 21 \mathrm{kDa})$ contains a ferroxidase site and is more numerous in ferritin isolated from heart and skeletal muscles (May et al., 2010). The $\mathrm{H}$ and L subunits are isomorphous and share the same tertiary structure with a bundle of four antiparallel $\alpha$-helices, a shorter helix on top of them (see Fig. 1), and loops connecting the helices (Stefanini et al., 1996; Massover, 1993). The subunits are roughly cylindrical, a little more than $5 \mathrm{~nm}$ long and $2.5 \mathrm{~nm}$ wide. The L subunits provide the assembled molecule a greater stability towards chemical and physical agents than do the $\mathrm{H}$ subunits (Yoshizawa et al., 2007). Ferritin and apoferritin exhibit channels at the intersection of the subunits, through which certain ions or molecules can travel. These channels are critical for ferritin's ability to release iron in a controlled fashion. 


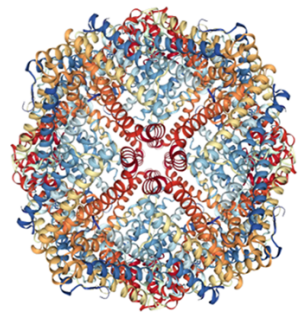

Ferritin

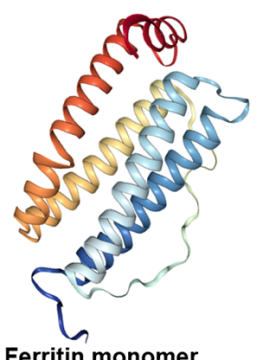

Ferritin monomer

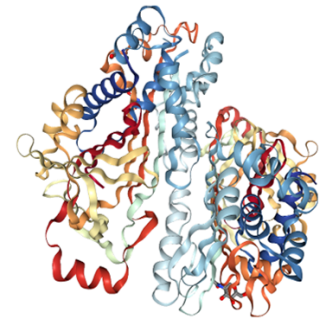

Ovalbumin

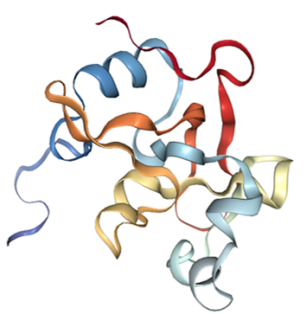

Class I hydrophobin DewA

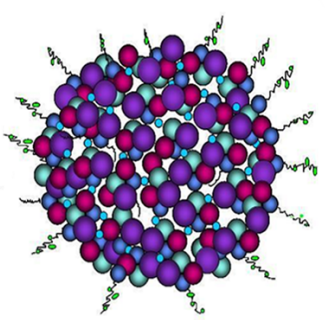

Casein micelle

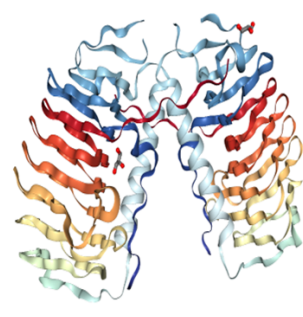

LelBP

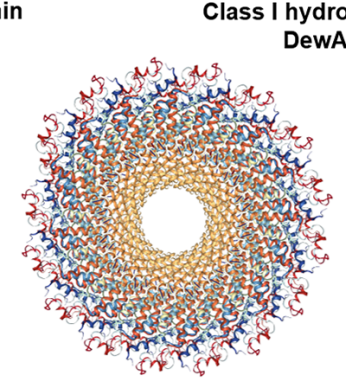

Tobacco mosaic virus (TMV)

Figure 1. Structures of the investigated proteins and the tobacco mosaic virus: horse spleen (apo)ferritin cage and (apo)ferritin monomer (PDB ID: 4V1W, Russo and Passmore, 2014), chicken ovalbumin (PDB ID: 1OVA, Stein et al., 1991), hydrophobin class I DewA (PDB

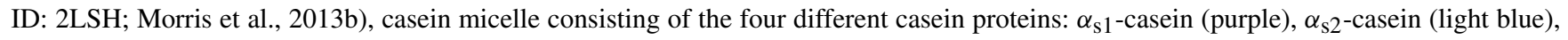
$\beta$-casein (red), $\kappa$-casein (dark blue with tail) (adapted from Rebouillat and Ortega-Requena, 2015), ice-binding protein LeIBP dimer (PDB ID: 3UYU, Lee et al., 2012), and tobacco mosaic virus (TMV) (PDB ID: 3J06; Ge and Zhou, 2011).

In this study, commercially available ferritin isolated from horse spleen is used. Apoferritin is obtained from ferritin by removing the iron oxide. Horse spleen apoferritin consists of $85 \%-90 \% \mathrm{~L}$ and $10 \%-15 \% \mathrm{H}$ chains (Stefanini et al., 1996; May et al., 2010). From sedimentation velocity measurements molar masses of $440-500 \mathrm{kDa}$ (Thomas et al., 1998; May et al., 2010; Ghirlando et al., 2016) are estimated for apoferritin while the calculation based on the subunit molar masses determined from cDNA sequences $(\mathrm{H}$ type: $21269 \mathrm{Da}$, L type: $19978 \mathrm{Da}$ ) yields $481.2 \mathrm{kDa}$ (assuming $85 \% \mathrm{~L}$ and $15 \% \mathrm{H}$ chains).

Two different batches of horse spleen ferritin and apoferritin saline solutions $(0.15$ and $0.135 \mathrm{M} \mathrm{NaCl}$, respectively) were used $(0.2 \mu \mathrm{m}$ filtered). Both were purchased from Sigma-Aldrich (product number A3641 for apoferritin and F4503 for ferritin). Batch 1 of ferritin and apoferritin was used for $\mathrm{pH}$ variation and stress experiments. Batch 1 of apoferritin with batch number SLBD5084V and the quality release date of 10 January 2013 has a concentration specified by Sigma-Aldrich of $37 \mathrm{mg} \mathrm{mL}^{-1}$, while our own measurements by the Bradford protein assay (Bradford, 1976) yielded $33.2 \mathrm{mg} \mathrm{mL}^{-1}$. Batch 1 of ferritin with the batch number SLBQ9541V and a release date of 30 June 2016 has a concentration specified by Sigma-Aldrich of $55 \mathrm{mg} \mathrm{mL}^{-1}$ compared to our own measurements yielding $49.7 \mathrm{mg} \mathrm{mL}^{-1}$. Note that for ferritin we provide the protein mass concentration, and the iron oxide is not counted to provide better comparison to the other proteins. Batch 2 of apoferritin (batch number SLBR2614V) was used for the dilution se- ries, the disassembly-reassembly experiment, and the refreeze experiments. It has the release date of 25 August 2016 and a specified concentration of $43 \mathrm{mg} \mathrm{mL}^{-1}$. Batch 2 of ferritin (batch number SLBV7127) with a specified concentration of $61 \mathrm{mg} \mathrm{mL}^{-1}$ has the quality release date of 13 December 2017. The saline solutions purchased from Sigma-Aldrich were diluted with pure water (purchased from Sigma-Aldrich) for IN experiments. Apoferritin solutions are colourless whereas ferritin solutions present a yellow-orange colour due to the presence of $\mathrm{Fe}^{3+}$ (see Fig. S1 of the Supplement).

A part of batch 2 of ferritin and apoferritin was dialysed against ammonium bicarbonate buffer for $96 \mathrm{~h}$. For this purpose, the samples were suspended in $10 \mathrm{mM}$ ammonium bicarbonate (Sigma-Aldrich, 09830) pH 7.4-7.6 prepared with Milli-Q water. Dialysis was achieved by using 10000 MWCO dialysis cassettes (Thermo Scientific) for a period of $96 \mathrm{~h}$, with the ammonium bicarbonate buffer replaced every $24 \mathrm{~h}$.

\subsubsection{Ovalbumin}

Ovalbumin is a protein found in large quantities in avian egg white, most probably serving as a biological reserve of amino acids. It is a non-inhibitory member of the serine protease inhibitor (serpin) superfamily with a molecular weight of $\sim 44.3 \mathrm{kDa}$ (385 amino acids) (Huntington and Stein, 2001; Stein et al., 1991). Ovalbumin from chicken egg white 
was purchased from Sigma-Aldrich (A5503) as a lyophilized powder ( $\geq 98 \%$ purity).

\subsubsection{Casein}

Casein is a major component of milk, giving it its white colour and unique texture (e.g. Ozeki et al., 2009). There are four types of casein, namely $\alpha_{\mathrm{s}^{-}}, \alpha_{\mathrm{s} 2^{-}}, \beta$-, and $\kappa$-casein with molecular weights between 19 and $25 \mathrm{kDa}$. These proteins adopt flexible conformations, albeit with significant amounts of secondary and, probably, tertiary structure (Swaisgood, 1993; Sunde et al., 2017). All four types of casein together with colloidal calcium phosphate are associated with highly hydrated micelles with average diameters of 150 to $200 \mathrm{~nm}$ (Dalgleish and Corredig, 2012) as shown in Fig. 1. The association is governed by weak hydrophobic interactions between casein proteins and by binding of calcium through the phosphoserine groups of $\alpha_{\mathrm{s} 1^{-}}, \alpha_{\mathrm{s} 2^{-}}$, and $\beta$-casein, leading to the formation of calcium phosphate nanoclusters within the micelles (Lucey and Horne, 2018). Phosphorylated serine is lacking in $\kappa$-casein, which is located on the outer surface of the casein micelles (Sunde et al., 2017). Casein from bovine milk containing all types of casein was used in this work (Sigma, C7078; technical grade).

\subsubsection{Hydrophobins HPA and HPB}

Hydrophobins are small cysteine-rich proteins of about 100 amino acids (MW $\approx 10 \mathrm{kDa}$ ) that are secreted by filamentous fungi. They can self-assemble into amphipathic monolayers on hydrophobic and hydrophilic surfaces as well as on interfaces (Morris et al., 2013b). Class I and class II hydrophobins are discriminated based on their hydropathy patterns and stability towards solvents and detergents (Wessels, 1996; Wohlleben et al., 2010). In Fig. 1, the structure of a class I hydrophobin, DewA, is depicted.

In this study, fusion hydrophobins $\mathrm{H}^{*}$ Protein A (HPA) and $\mathrm{H}^{*}$ Protein B (HPB) supplied by BASF (Ludwigshafen, Germany) were used. These hydrophobins combine the class I hydrophobin DewA of Aspergillus nidulans and the synthase yaaD protein of Bacillus subtilis as fusion partners. HPA contains the whole yaaD protein, and HPB is only a truncated form (Wohlleben et al., 2010). Both HPA and HPB carry a hexahistidine terminus.

\subsubsection{Ice-binding protein LeIBP}

LeIBP is a glycosylated ice-binding protein with a molecular mass of $\sim 25 \mathrm{kDa}$ that is produced by Arctic yeast Leucosporidium sp. AY30 (Lee et al., 2012). It consists of a right handed $\beta$-helix fold, a long helix $(\alpha 3)$, and a $\mathrm{C}$-terminal hydrophobic loop. The $\beta$-helical fold features aligned Thr/Ser/Ala residues that are considered critical for ice binding. LeIBP forms dimers in solution, most probably via the hydrophobic surfaces of helix $\alpha 3$ and the $\mathrm{C}$-terminal loop, thus concealing the hydrophobic areas from the solvent
(Lee et al., 2012) as shown in Fig. 1. LeIBP used in this study was supplied by Se Jong Han from the Korea Polar Research Institute (KOPRI).

\subsubsection{Tobacco mosaic virus (TMV)}

The Tobacco mosaic virus (TMV) is assembled from a single-stranded RNA (making up only $5 \%$ of the mass), enveloped in 2100 identical helically arranged proteins. The thus formed hollow tube is $300 \mathrm{~nm}$ in length, with an external diameter of $18 \mathrm{~nm}$ (Eleta-Lopez and Calò, 2017; Alonso et al., 2013). TMV infects plants of the family of Solanaceae such us tobacco, tomato, or pepper, causing characteristic mosaic-like patterns; it is harmless to mammals. A TMV suspension $\left(10 \mathrm{mg} \mathrm{mL}^{-1}\right)$ was provided by Christina Wege (University of Stuttgart, Germany)

\subsection{Freezing experiments performed with DRINCZ}

Drop freezing assays investigate heterogeneous ice nucleation in an array of droplets of microlitre volumes and are able to detect low concentrations of INPs. Droplet freezing experiments were first reported by Vali and Stansbury (1966) and have since then been used in numerous studies (e.g. Stopelli et al., 2014; Hill et al., 2014; Hiranuma et al., 2015b; Budke and Koop, 2015; Tobo, 2016).

The recently developed DRoplet Ice Nuclei Counter Zurich (DRINCZ) is used for IN measurements (David et al., 2019) in this study. The drop freezing setup consists of four main parts: (i) a 96-well tray containing in each well $50 \mu \mathrm{L}$ of liquid sample, (ii) a recirculating chiller bath filled with ethanol to cool the sample, (iii) LED lights and a USB camera to observe the freezing of the wells, and (iv) a computer to control the sample temperature and cooling rate, as well as to record and evaluate pictures of the freezing wells.

A home-made lamp built out of LED strips enclosed in an ethanol proof housing is submerged in the cooler liquid to illuminate the 96-well tray from below. The USB camera is placed above the chiller and directed toward the tray. Images are recorded every $15 \mathrm{~s}$, which corresponds to a picture taken every $0.25^{\circ} \mathrm{C}$, when the bath is cooled at $1^{\circ} \mathrm{C} \mathrm{min}^{-1}$.

In a typical experiment, $50 \mu \mathrm{L}$ aliquots of the sample solutions are pipetted with an automatic eight-channel pipette into the 96-well tray, consisting of 8 wells by 12 wells of $200 \mu \mathrm{L}$ (732-2386, VWR, USA). The wells are sealed with a transparent sealable foil (PlateMax ${ }^{\circledR}$ CyclerSeal Sealing film, Axygen Inc.) to prevent any impurities from settling into the samples. The tray is placed in the ethanol bath of the chiller (LAUDA Proline RP 845 refrigerating circulator, Lauda-Königshofen, Germany). A temperature ramp $\left(-1{ }^{\circ} \mathrm{C} \mathrm{min}-1\right)$ is adjusted via the control software (LabVIEW). During the freezing process the wells turn dark, because small ice crystals scatter light more effectively than liquid water. This decrease in transmission is evaluated automatically by a MATLAB code to detect the initial decrease 
in brightness which is taken as the instant of IN (see David et al., 2019, for a detailed description). For the measurements performed with batch 2 (dilution series, disassemblyreassembly, and refreeze experiments), the bath leveller, which keeps the ethanol bath level constant during a cooling ramp, was used as described in David et al. (2019). Protein and virus screening and experiments with batch 1 of ferritin and apoferritin were performed without the bath leveller. In order to correct the temperature difference between the samples within the 96-well tray and the temperature reported by the chiller, a temperature correction was performed as described in David et al. (2019).

Frozen fractions (FFs) were converted to cumulative active sites as given in Vali (2019):

$K(T)=\frac{1}{V} \cdot\left(\ln N_{0}-\ln N(T)\right)$,

with $N_{0}$ and $N(T)$ as the total number of wells (96) and the number of frozen wells at temperature $T$, respectively, and $V$ is the volume of each aliquot. Differential active site densities were calculated as

$k(T)=\frac{1}{V \cdot \Delta T} \ln \left(1-\frac{\Delta N}{N(T)}\right)$,

where $\Delta N$ is the number of wells freezing within the temperature interval $\Delta T$. The cumulative active site density is obtained from the differential one through

$K(T)=\sum_{0}^{T} k(T) \cdot \Delta T$.

When FF curves overlapped with freezing of water devoid of sample, a background correction was performed by subtracting the differential active site density $k(T)$ of the background from that of the sample as outlined in Vali (2019) and David et al. (2019).

\subsection{Sample preparation}

\subsubsection{Screening experiments}

For screening experiments, solutions were prepared with Sigma-Aldrich (SA) water (molecular biology reagent water from Sigma-Aldrich).

\subsection{2 pH variations}

Six different buffers with $\mathrm{pH}$ values between 0 and 9.5 were prepared (see Table 1). The buffer at $\mathrm{pH} 0$ was prepared adding $8.58 \mathrm{~mL} \mathrm{HCl}$ (hydrochloric acid $37 \%$, Merck $\mathrm{KGaA}$, Darmstadt) to $100 \mathrm{~mL}$ of SA water. The buffer at pH 2 was prepared with $\mathrm{KCl}$ (Potassium chloride $>99.5 \%$, Sigma-Aldrich, Missouri, USA) and $\mathrm{HCl}$ (37\%). The $\mathrm{pH} 3.5$ and $\mathrm{pH} 5$ buffers were prepared using citric acid $\left(\mathrm{C}_{6} \mathrm{H}_{8} \mathrm{O}_{7}\right.$, $99 \%$, Sigma-Aldrich, Missouri, USA) and $\mathrm{Na}_{2} \mathrm{HPO}_{4} \cdot 7 \mathrm{H}_{2} \mathrm{O}$ (sodium phosphate dibasic heptahydrate, Sigma-Aldrich,
Missouri, USA). The buffer at $\mathrm{pH} 7$ was prepared with HEPES $\left(\mathrm{C}_{8} \mathrm{H}_{18} \mathrm{~N}_{2} \mathrm{O}_{4} \mathrm{~S},>99.5 \%\right.$, Sigma-Aldrich, Missouri, USA) and $\mathrm{NaOH}$ (sodium hydroxide, $>98 \%$, Sigma-Aldrich, Missouri, USA). Buffer $\mathrm{pH} 9.5$ was prepared with $\mathrm{Na}_{2} \mathrm{~B}_{4} \mathrm{O}_{7}$. $10 \mathrm{H}_{2} \mathrm{O}$ (sodium tetraborate decahydrate, Merck KGaA, Darmstadt) and $\mathrm{NaOH}(>98 \%)$. All $\mathrm{pH}$ values were verified with a $\mathrm{pH}$ meter (691 $\mathrm{pH}$ meter, Metrohm, Swiss).

Two different concentrations of apoferritin (0.34 and $\left.0.036 \mathrm{mg} \mathrm{mL}^{-1}\right)$ and ferritin $\left(0.39\right.$ and $0.04 \mathrm{mg} \mathrm{mL}^{-1}$ protein) solutions were prepared from batch 1 of apoferritin and ferritin. The precise amount of ferritin and apoferritin was added to the various buffers to assess the effect of $\mathrm{pH}$ on the IN activity. Samples were kept in these buffers overnight. The $\mathrm{pH}$ of each solution was measured before a freezing experiment was carried out. The results are shown in Table 1.

\subsection{Stress treatments}

For the heat treatment, apoferritin solutions (batch 1, $0.34 \mathrm{mg} \mathrm{mL}^{-1}$ ) were prepared with $\mathrm{SA}$ water and heated to $110^{\circ} \mathrm{C}$ for $5 \mathrm{~h}$. To prevent water loss, the bottles were loosely covered by a cap. For the combined heat and low-pH treatment, a solution of $0.34 \mathrm{mg} \mathrm{mL}^{-1}$ concentration (batch 1 ) was prepared in $\mathrm{pH} 0$ buffer and submitted to the same heat treatment. We used glass beakers closed with a loosely screwed stopper to prevent overpressure.

\subsection{Disassembly-reassembly experiments}

A two-step solution preparation procedure was used to achieve disassembly and reassembly.

For the disassembly experiment, the apoferritin solution (batch 2) was diluted with $\mathrm{pH} 2$ buffer to prepare $\mathrm{pH} 2$ apoferritin solutions with 0.036 and $0.018 \mathrm{mg} \mathrm{mL}^{-1}$ concentrations. These solutions were allowed to rest for $1 \mathrm{~h}$ before filling the 96-well tray for DRINCZ freezing measurements.

For disassembly-reassembly experiments, the apoferritin solution (batch 2) was diluted with the $\mathrm{pH} 2$ buffer to prepare $\mathrm{pH} 2$ apoferritin solutions with 0.072 and $0.036 \mathrm{mg} \mathrm{mL}^{-1}$ concentrations and subsequently allowed to rest for $1 \mathrm{~h}$. For reassembly, $0.1 \mathrm{MNaOH}$ was added to the $\mathrm{pH} 2$ solutions until reaching $\mathrm{pH}$ 8. Then $\mathrm{SA}$ water was added to obtain the desired apoferritin concentrations of 0.036 and $0.018 \mathrm{mg} \mathrm{mL}^{-1}$. Before preparation for the DRINCZ experiments, the solutions were allowed to rest for $30 \mathrm{~min}$.

\subsection{Refreeze experiments}

Apoferritin solutions (batch 2, concentrations of 0.34, 0.036, and $0.018 \mathrm{mg} \mathrm{mL}^{-1}$ ) were prepared and tested for IN activity in DRINCZ. The IN activity of the same 96-well tray was tested again during the following $4 \mathrm{~d}$ in refreeze experiments. Between experiments, the tray was stored at $4{ }^{\circ} \mathrm{C}$. 
Table 1. $\mathrm{pH}$ values of the apoferritin and ferritin solutions in water and the buffered samples.

\begin{tabular}{|c|c|c|c|c|}
\hline \multirow[t]{3}{*}{ Solution/buffer composition } & \multicolumn{4}{|c|}{$\mathrm{pH}$} \\
\hline & \multicolumn{2}{|c|}{ Apoferritin } & \multicolumn{2}{|c|}{ Ferritin } \\
\hline & $0.34 \mathrm{mg} \mathrm{mL}^{-1}$ & $0.036 \mathrm{mg} \mathrm{mL}^{-1}$ & $0.39 \mathrm{mg} \mathrm{mL}^{-1}$ & $0.04 \mathrm{mg} \mathrm{mL}^{-1}$ \\
\hline Sigma-Aldrich water & 7.00 & 6.97 & 7.60 & 7.27 \\
\hline $85.8 \mathrm{mM} \mathrm{HCl}$ & 0.27 & 0.16 & 0.02 & 0.07 \\
\hline $50 \mathrm{mM} \mathrm{KCl}+10.6 \mathrm{mM} \mathrm{HCl}$ & 2.08 & 2.07 & 2.08 & 2.06 \\
\hline $71.5 \mathrm{mM}$ citric acid $+57 \mathrm{mM} \mathrm{Na} \mathrm{HPO}_{4} \cdot 7 \mathrm{H}_{2} \mathrm{O}$ & 3.52 & 3.47 & 3.67 & 3.46 \\
\hline $48.5 \mathrm{mM}$ citric acid $+103 \mathrm{mM} \mathrm{Na}_{2} \mathrm{HPO}_{4} \cdot 7 \mathrm{H}_{2} \mathrm{O}$ & 5.27 & 5.07 & 5.14 & 5.06 \\
\hline $0.5 \mathrm{mM}$ HEPES (adjusted with $5 \mathrm{M} \mathrm{NaOH}$ ) & 7.06 & 7.11 & 7.07 & 7.12 \\
\hline $12.5 \mathrm{mM} \mathrm{Na}_{2} \mathrm{~B}_{4} \mathrm{O}_{7} \cdot 10 \mathrm{H}_{2} \mathrm{O}+3.6 \mathrm{mM} \mathrm{NaOH}$ & 9.50 & 9.51 & 9.49 & 9.48 \\
\hline
\end{tabular}

\subsection{Dynamic light scattering}

The hydrodynamic diameter of nanostructures in protein solutions was determined by dynamic light scattering (DLS) using a Zetasizer Nano ZS (Malvern Instruments Ltd., Malvern, Great Britain). Three runs were performed in three replicates, resulting in nine measurements per sample. To obtain consistent results, noise was reduced by increasing measurement times for low-concentration samples. The same procedure was followed for reference solutions of polystyrene latex and gold nanoparticles of known diameters (see Fig. S2). The hydrodynamic diameter ( $z$ average) and volume-weighted distribution (Stetefeld et al., 2016) of protein assemblies were calculated with the equipment software (v.7.12, Malvern Instruments Ltd., Malvern, Great Britain) without any further data processing, hence assuming spherical shapes. Size-resolved concentrations were obtained by multiplying the volume-weighted distribution by the solution concentration.

\section{Results and discussion}

\subsection{IN activity screening of common proteins and a virus}

All investigated proteins (and TMV) induced freezing clearly above the reference curve of pure SA water, given as the grey line in Fig. 2a. However, they exhibited large variations in onset $\left(-4\right.$ to $\left.-12^{\circ} \mathrm{C}\right)$ and complete freezing $(\mathrm{FF}=1)$ temperatures $\left(-7\right.$ to $\left.-23{ }^{\circ} \mathrm{C}\right)$. Apoferritin proved to be the most IN-active sample with a freezing onset of $-4^{\circ} \mathrm{C}$ and complete freezing at $-7^{\circ} \mathrm{C}$ despite being less concentrated $\left(0.34 \mathrm{mg} \mathrm{mL}^{-1}\right)$ than the other proteins $\left(1 \mathrm{mg} \mathrm{mL}^{-1}\right)$. The milk protein casein showed a similarly steep freezing curve as apoferritin and ferritin, however, shifted to lower temperatures with an onset at $-8{ }^{\circ} \mathrm{C}$ and complete freezing at $-13^{\circ} \mathrm{C}$. The freezing curves of the egg protein ovalbumin, the ice-binding protein LeIBP, and the hydrophobins HPA and HPB all exhibit freezing onsets between -6 and $-8{ }^{\circ} \mathrm{C}$, a plateau at about $-10^{\circ} \mathrm{C}$, followed by a steeper increase, resulting in $\mathrm{FF}=1$ between -19 and $-23^{\circ} \mathrm{C}$. This indicates the presence of two different types of sites: rare ones with activity above $-10^{\circ} \mathrm{C}$ and more common ones with activity between -10 and $-23^{\circ} \mathrm{C}$. The fusion hydrophobin HPB, which contains only a truncated version of the yaaD protein, is more IN active than HPA, which contains the full yaaD protein, suggesting that the hydrophobin part of the fusion protein is relevant for the observed IN activity. TMV shows a lower IN activity than the proteins with freezing onset only at $-12{ }^{\circ} \mathrm{C}$, however, it is also the most dilute sample with a concentration of only $0.002 \mathrm{mg} \mathrm{mL}^{-1}$. If we compare the ice-nucleation activity in terms of cumulative active site densities (Fig. 2b), TMV exhibits a higher active site density than the hydrophobins, the ice-binding protein, and ovalbumin for temperatures below $-14^{\circ} \mathrm{C}$.

In the following, we concentrate on the IN activity of apoferritin and ferritin samples to find out more about the sites that are responsible for their IN activity.

\subsection{Freezing experiments performed with apoferritin and ferritin}

\subsubsection{Batch and concentration dependence}

Frozen fractions from two different batches of apoferritin and ferritin with two different concentrations are shown in Fig. 3. For apoferritin (panel a), the higher concentrated solution $\left(0.34 \mathrm{mg} \mathrm{mL}^{-1}\right)$ freezes in a narrow temperature range from -4 to $-7^{\circ} \mathrm{C}$ for batch 1 and between -4 and $-13^{\circ} \mathrm{C}$ for batch 2 , indicating a higher IN activity of batch 1 than of batch 2 . However, for the lower concentration $\left(0.036 \mathrm{mg} \mathrm{mL}^{-1}\right)$ the situation is reversed. While the onsets for both batches are at $-5^{\circ} \mathrm{C}$, batch 2 reaches $\mathrm{FF}=1$ already at $-17^{\circ} \mathrm{C}$ (light blue line) while batch 1 reaches $\mathrm{FF}=1$ only at $-22^{\circ} \mathrm{C}$ (dark blue line), indicating a higher IN activity of batch 2 compared to batch 1 for this concentration.

For ferritin (Fig. 3b), the difference between batches is even larger. The higher concentrated solution $\left(0.39 \mathrm{mg} \mathrm{mL}^{-1}\right.$ protein) freezes in the temperature range between -4 and 


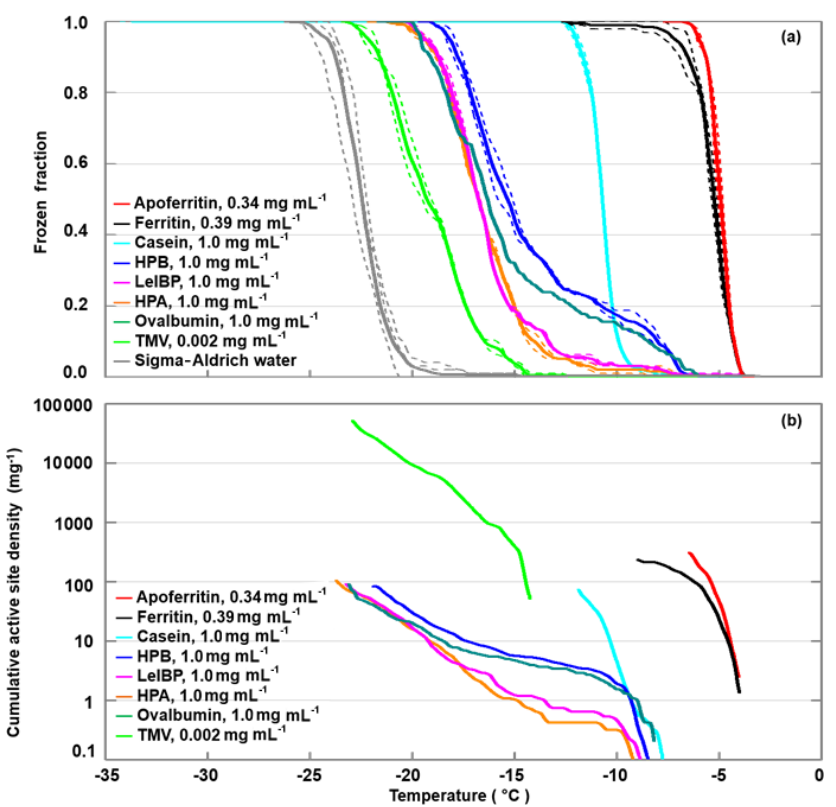

Figure 2. DRINCZ experiments performed with apoferritin $\left(0.34 \mathrm{mg} \mathrm{mL}^{-1}\right.$, batch 1$)$, ferritin $\left(0.39 \mathrm{mg} \mathrm{mL}^{-1}\right.$, batch 1$)$, casein $\left(1.0 \mathrm{mg} \mathrm{mL}^{-1}\right)$, HPA $\left(1.0 \mathrm{mg} \mathrm{mL}^{-1}\right)$, HPB $\left(1.0 \mathrm{mg} \mathrm{mL}^{-1}\right)$, LeIBP $\left(1.0 \mathrm{mg} \mathrm{mL}^{-1}\right)$, ovalbumin $\left(1.0 \mathrm{mg} \mathrm{mL}^{-1}\right)$, and TMV $\left(0.002 \mathrm{mg} \mathrm{mL}^{-1}\right)$. (a) Frozen fraction as a function of temperature. For comparison, freezing of pure SA water is also shown. Singlefreezing runs are shown as dashed lines and the mean as the thick solid lines. (b) Cumulative active site densities.

$-12{ }^{\circ} \mathrm{C}$ for batch 1 and between -7.5 and $-20^{\circ} \mathrm{C}$ for batch 2. For the more dilute solutions $\left(0.04 \mathrm{mg} \mathrm{mL}^{-1}\right)$, the freezing was observed to occur between -4 and $-21{ }^{\circ} \mathrm{C}$ for batch 1 and between -10 and $-22.5^{\circ} \mathrm{C}$ for batch 2 . This is a remarkable difference in the IN activity between the two batches, calling into question whether the fully assembled cage monomer, which is the dominant species present in the solution, is the IN-active species.

Therefore, to investigate the influence of the buffer solution and random impurities on IN activity, a portion of apoferritin and ferritin from batch 2 was dialysed. By means of dialysis, salts and other compounds potentially present in the commercial protein solution are removed. The frozen fraction curves of the dialysed samples practically overlap for the lower concentrations and show a slight decrease for the higher concentrations for ferritin and a slight increase for apoferritin. The similarity between the IN activity of the dialysed and the original samples makes it unlikely that random impurities are responsible for the observed IN activity. Overall, the IN activity of ferritin is lower than the one of apoferritin, which makes it unlikely that iron plays an active part in ice nucleation by ferritin. Rather, the presence of iron within the cages seems to reduce the IN activity of the proteins.
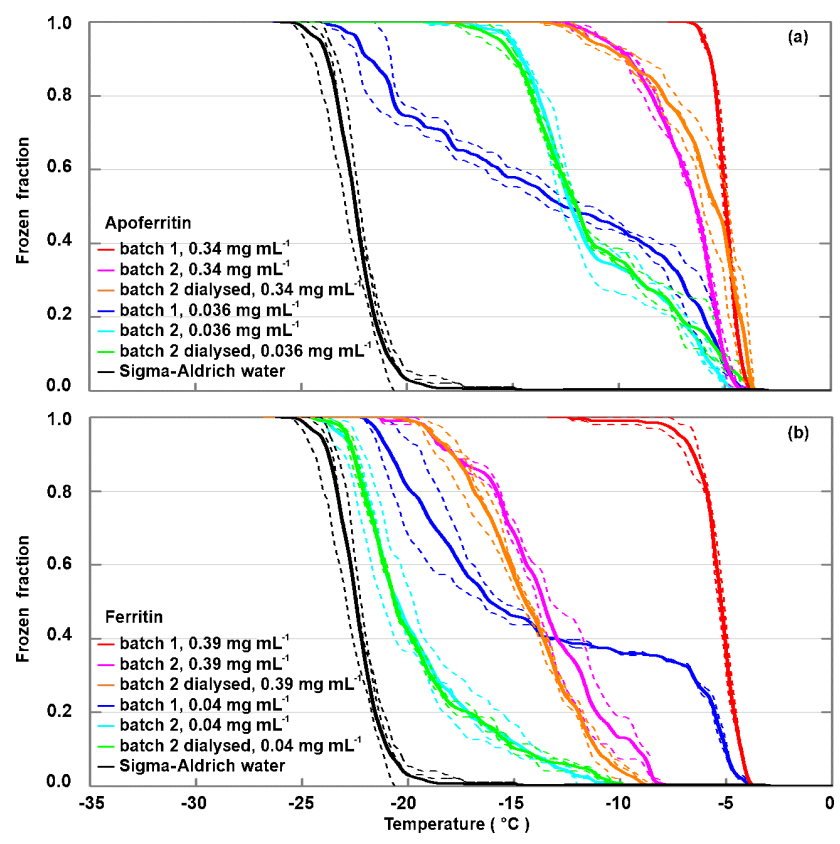

Figure 3. Batch dependence of the IN activity of apoferritin and ferritin for two different concentrations. (a) Frozen fraction as a function of temperature for batches 1 and 2 of apoferritin solutions with concentrations of $0.34 \mathrm{mg} \mathrm{mL}^{-1}$ and $0.036 \mathrm{mg} \mathrm{mL}^{-1}$ and a dialysed solution of batch 2 prepared with the lower concentration (see Material and methods for details). (b) Frozen fraction as a function of temperature for batches 1 and 2 of ferritin solutions with concentrations of 0.39 and $0.04 \mathrm{mg} \mathrm{mL}^{-1}$ and a dialysed solution from batch 2 prepared with the lower concentration. Two to three DRINCZ experiments were performed for each concentration (dashed lines), and the mean is shown as the thick solid lines.

To identify the origin of the IN-active sites of the ferritin and apoferritin samples, we explored how $\mathrm{pH}$, temperature, and dilution influence their IN activity.

\subsection{2 pH variations}

To test the $\mathrm{pH}$ dependence of IN activity, we performed freezing experiments with apoferritin and ferritin samples in buffer solutions with $\mathrm{pH}$ from 0 to 9.5. Figure 4 shows the FF curves for apoferritin, batch 1, with concentrations of $0.036 \mathrm{mg} \mathrm{mL}^{-1}$ (panel a) and $0.34 \mathrm{mg} \mathrm{mL}^{-1}$ (panel c), and for ferritin, batch 1 , with concentrations of $0.04 \mathrm{mg} \mathrm{mL}^{-1}$ (panel b) and $0.39 \mathrm{mg} \mathrm{mL}^{-1}$ (panel d).

With variations of up to $2{ }^{\circ} \mathrm{C}$, the freezing curves of the more highly concentrated apoferritin and ferritin samples exhibit only a slight $\mathrm{pH}$ dependence in the range from $\mathrm{pH} 2$ to 9.5 , with the lowest freezing temperatures at $\mathrm{pH} 7$, while $\mathrm{pH} 2-5$ curves are shifted to slightly higher temperatures, and the maximum is at $\mathrm{pH} 9.5$. The freezing curves of the more dilute samples show the same $\mathrm{pH}$ dependence but with a slightly larger spread in temperature. The $\mathrm{pH} 0$ freezing curves are clearly offset to a lower temperature but 

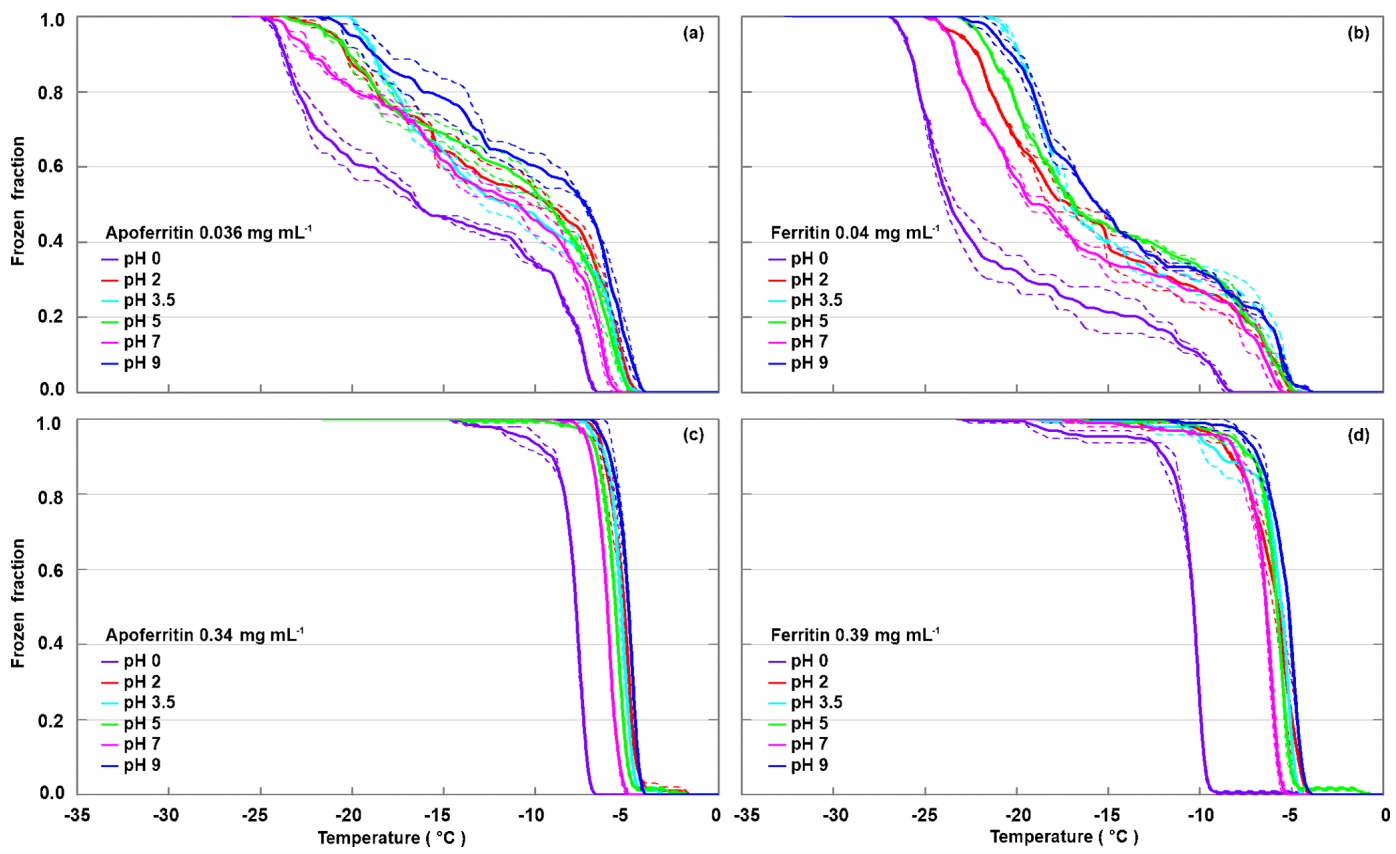

Figure 4. $\mathrm{pH}$ dependence of frozen fractions at six different $\mathrm{pH}$ values for apoferritin (batch $\left.1,0.036 \mathrm{mg} \mathrm{mL}^{-1}\right)(\mathbf{a})$, ferritin (batch 1 , $0.04 \mathrm{mg} \mathrm{mL}^{-1}$ ) (b), apoferritin (batch 1, $0.34 \mathrm{mg} \mathrm{mL}^{-1}$ ) (c), and ferritin (batch 1, $0.39 \mathrm{mg} \mathrm{mL}^{-1}$ ) (d). Two to three DRINCZ experiments were performed for each concentration (dashed lines) and the means are shown as the thick solid lines.

still show high IN activity, which is astonishing considering that protein coagulation was clearly visible in these samples (see Fig. S3). Apoferritin cages are positively charged below $\mathrm{pH} 4.0$ and negatively charged above $\mathrm{pH} 4.6$ (Petsev and Vekilov, 2000; Valle-Delgado et al., 2005). The conformity in freezing temperatures below and above the isoelectric point at about $\mathrm{pH} 4$ shows that the net charge of apoferritin has no significant influence on IN activity.

Moreover, the ferritin cages undergo conformational changes in the investigated $\mathrm{pH}$ range, which also do not seem to influence IN activity strongly. Namely, small-angle X-ray scattering of horse spleen ferritin and apoferritin showed that the apoferritin cage is stable over the $\mathrm{pH}$ range from 3.4 to 10 (Kim et al., 2011), but when the $\mathrm{pH}$ decreases from 3.40 to 0.80 , the cage disassembles stepwise, by first forming a hollow sphere with two holes, then a headset-shaped structure, and finally rod-like dimers. Disintegration and aggregation of horse spleen ferritin at low and high $\mathrm{pH}$ were also observed by Crichton and Bryce (1973), using a sedimentationvelocity technique. They observed that fully assembled cages prevailed for $\mathrm{pH}$ values between 2.8 and 10.6, and assembled cages and subunits were present at $\mathrm{pH}=2.8-1.6$ and $\mathrm{pH}=$ 10.6-13.0. At $\mathrm{pH}=1.6-1.0$ subunits were the only identified species, while below $\mathrm{pH} 1.0$ the subunits agglomerated to larger (non-cage) aggregates. The dissociation stops at the level of dimers, since dissociation into subunit monomers does not seem to occur without full denaturation of the protein (Linder et al., 1989). Crichton and Bryce (1973) explained the disassembly at low $\mathrm{pH}$ by changes in conforma- tion of apoferritin due to the protonation of carboxyl groups with pKa values of 3.29, initiating the transfer of one tryptophan residue from the interior of the protein to the exterior, hence exposing it to solvent. Subunit dissociation involves the transfer of four to five tyrosine residues to a more hydrophilic environment, most likely to the solvent, accompanied by protonation of at least two carboxyl groups of $\mathrm{pKa}$ 2.16. Such changes in subunit conformation likely determine the apoferritin shell disassembly (Santambrogio et al., 1992). Agglomeration of apoferritin and ferritin below pH 1.0 is in accordance with the coagulation in our samples observed at $\mathrm{pH} 0$ (Fig. S3).

Despite the disintegration of the cages below pH 3.4 and agglomeration below $\mathrm{pH} 1$, the IN activity of apoferritin and ferritin solutions is hardly decreased at $\mathrm{pH} 2$ and still remarkably high at $\mathrm{pH} 0$. This makes it highly unlikely that fully assembled cages are required as the entities that provide IN activity to the apoferritin and ferritin samples. To exclude IN by non-proteinaceous species present as impurities in the ferritin and apoferritin samples, we performed stress tests to determine the stability limit of the ice-nucleating species.

\subsubsection{Stress treatments}

Figure 5 shows the decrease in FF depending on the treatment of apoferritin solutions (batch $1,0.34 \mathrm{mg} \mathrm{mL}^{-1}$ ). While $\mathrm{pH} 0$ decreases the IN activity only by $3{ }^{\circ} \mathrm{C}$, heating at $110^{\circ} \mathrm{C}$ for $5 \mathrm{~h}$ shifts freezing by $10-15^{\circ} \mathrm{C}$ to lower temperatures. Moreover, it leads to even stronger aggregation of the 


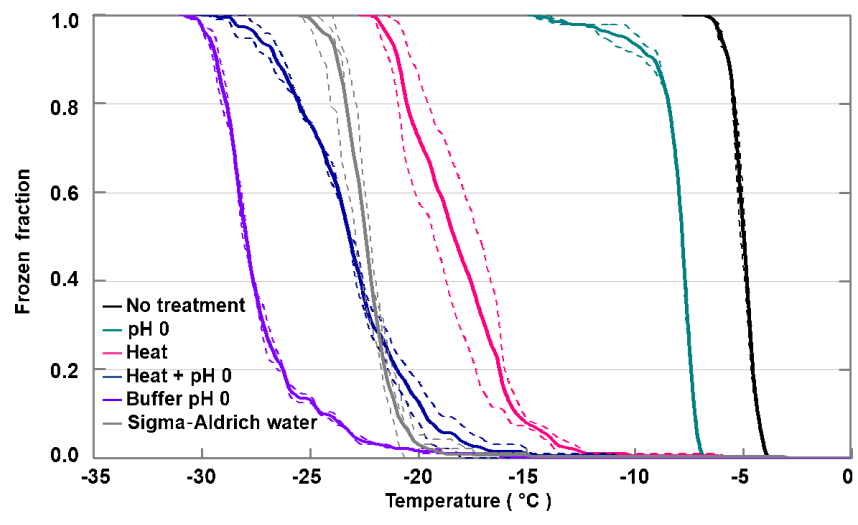

Figure 5. Stress treatments performed with apoferritin batch 1 $\left(0.34 \mathrm{mg} \mathrm{mL}^{-1}\right)$. Frozen fraction as a function of temperature for apoferritin in $\mathrm{pH} 0$ buffer, after heating an apoferritin solution in SA water for $5 \mathrm{~h}$ at $110^{\circ} \mathrm{C}$ and after heating an apoferritin solution at $\mathrm{pH} 0$ for $5 \mathrm{~h}$ at $110^{\circ} \mathrm{C}$. For comparison, freezing of SA water and of the buffer solution at $\mathrm{pH} 0$ is also shown. Two DRINCZ experiments were performed for each concentration (dashed lines) and the mean is shown as the thick solid lines.

ferritin and apoferritin samples (see Fig. S4) than exposure to $\mathrm{pH} 0$. If heating and $\mathrm{pH} 0$ are combined, freezing shifts to the temperature range observed for pure SA water but is still above freezing observed for the $\mathrm{pH} 0$ buffer reference sample. Visual inspection of the vials reveals that both the ferritin and apoferritin samples are now clear colourless solutions (see Fig. S3). This shows that low $\mathrm{pH}$ and heat need to be combined to completely disassemble the protein subunits and to remove the IN activity.

Indeed, ferritin and apoferritin have proven to be very heat resistant. Using UV-vis spectrophotometry and gel electrophoresis to investigate the thermostability of horse spleen apoferritin, Kudr et al. (2015) report small conformational changes already at $36^{\circ} \mathrm{C}$. Above $65^{\circ} \mathrm{C}$, the spherical cage structure is lost, accompanied by the release of subunits. This denaturation shows substantial reversibility upon cooling when heating is limited to a few degrees below $68^{\circ} \mathrm{C}$. Differential scanning calorimetry reveals the high thermal stability of the horse spleen apoferritin, with denaturation accompanied by aggregation and precipitation occurring only above $93{ }^{\circ} \mathrm{C}$ under neutral conditions (Stefanini et al., 1996). Evaluation of the enthalpy change suggests that the thermal denaturation does not lead to complete unfolding of the subunits. Moreover, denaturation displays significant reversibility after heating to temperatures only a few degrees below $93^{\circ} \mathrm{C}$. Yet, even at $100^{\circ} \mathrm{C}$, denaturation of horse spleen ferritin seems incomplete, since the majority of protein spheres appears intact in high-resolution electron microscopy, with only a minority being clearly disrupted even after boiling and cooling (Massover, 1978). The high thermal stability of ferritin and apoferritin is ascribed to intra- and intersubunit interactions (Santambrogio et al., 1992; Massover,
1993; Yoshizawa et al., 2007). Thus, IN activity persisting after heating for $5 \mathrm{~h}$ at $110^{\circ} \mathrm{C}$ is in agreement with the high thermal stability of ferritin and apoferritin. This strengthens the assumption that proteinaceous structures are responsible for the IN activity rather than non-proteinaceous impurities. Since horse spleen apoferritin from Sigma-Aldrich should be free of foreign proteins $(>99.9 \% \mathrm{w} / \mathrm{w})$ (Thomas et al., 1998), the IN activity of the horse spleen apoferritin sample indeed seems to arise from sites connected with apoferritin itself. To elucidate the abundance of such sites and to constrain the size of the IN-active entities, we prepared a dilution series for freezing and performed DLS experiments, allowing the correlation of active site densities with the size of apoferritin species present in solution.

\subsubsection{Apoferritin dilution series}

We diluted the apoferritin sample (batch 2) in steps of factors of 2 to 3 , until the freezing curve was close to the one of pure SA water. Figure 6 shows the freezing curves covering concentrations from $0.34 \mathrm{mg} \mathrm{mL}^{-1}$ to $0.56 \mu \mathrm{g} \mathrm{mL}^{-1}$ $(0.7-0.001 \mu \mathrm{M})$. The sample with the highest concentration is identical to batch 2 apoferritin shown in Fig. 2 with onset at $-4{ }^{\circ} \mathrm{C}$ and $\mathrm{FF}=1$ at $-13^{\circ} \mathrm{C}$. Dilution to $0.0045 \mathrm{mg} \mathrm{mL}^{-1}$ decreases $\mathrm{FF}$ above $-11^{\circ} \mathrm{C}$ from 1 to 0.1 , while even further dilution reduces freezing below $-11^{\circ} \mathrm{C}$, indicating the presence of two distinct freezing ranges. This division of freezing into two distinct ranges is also visible in the differential active site densities calculated using Eq. (2) (panel b), which display almost constant values of 10 to $100 \mathrm{mg}^{-1} \mathrm{~K}^{-1}$ between -5 and $-11^{\circ} \mathrm{C}$, followed by a steep increase to almost $1000 \mathrm{mg}^{-1} \mathrm{~K}^{-1}$ between -11 and $-15^{\circ} \mathrm{C}$ and a shallower increase when temperature is further decreased to $-22^{\circ} \mathrm{C}$. The division into two distinct freezing ranges is also visible in the cumulative active site densities calculated with Eq. (1) (panel c). Moreover, it can be seen that the active site densities between -4 and $-1{ }^{\circ} \mathrm{C}$ for apoferritin concentrations of $0.036 \mathrm{mg} \mathrm{mL}^{-1}$ and $0.009 \mathrm{mg} \mathrm{mL}^{-1}$ are slightly higher than for the other concentrations and that the active site densities for the lowest concentration of $0.56 \mu \mathrm{g} \mathrm{mL}-1$ feature a strong decrease between -17 and $-21^{\circ} \mathrm{C}$. However, the large contribution of SA water to the frozen fraction for this apoferritin concentration makes the active site density originating from apoferritin subject to large uncertainties.

To relate the freezing temperature to the size of apoferritin species present in the sample, we performed DLS measurements. Figure 7 presents the hydrodynamic diameter of apoferritin (batch 2) species present in the solution for concentrations from 0.34 to $0.0045 \mathrm{mg} \mathrm{mL}^{-1}$. At lower concentrations, no reproducible DLS curves could be obtained due to the high dilution. The size distribution is strongly dominated by the major peak at $12.5 \pm 0.3 \mathrm{~nm}$. Moreover, there are two additional weak peaks with maxima around 500 and $5000 \mathrm{~nm}$ that are shown on an enlarged scale in Fig. 7, suggesting the presence of larger aggregate species. The peak 

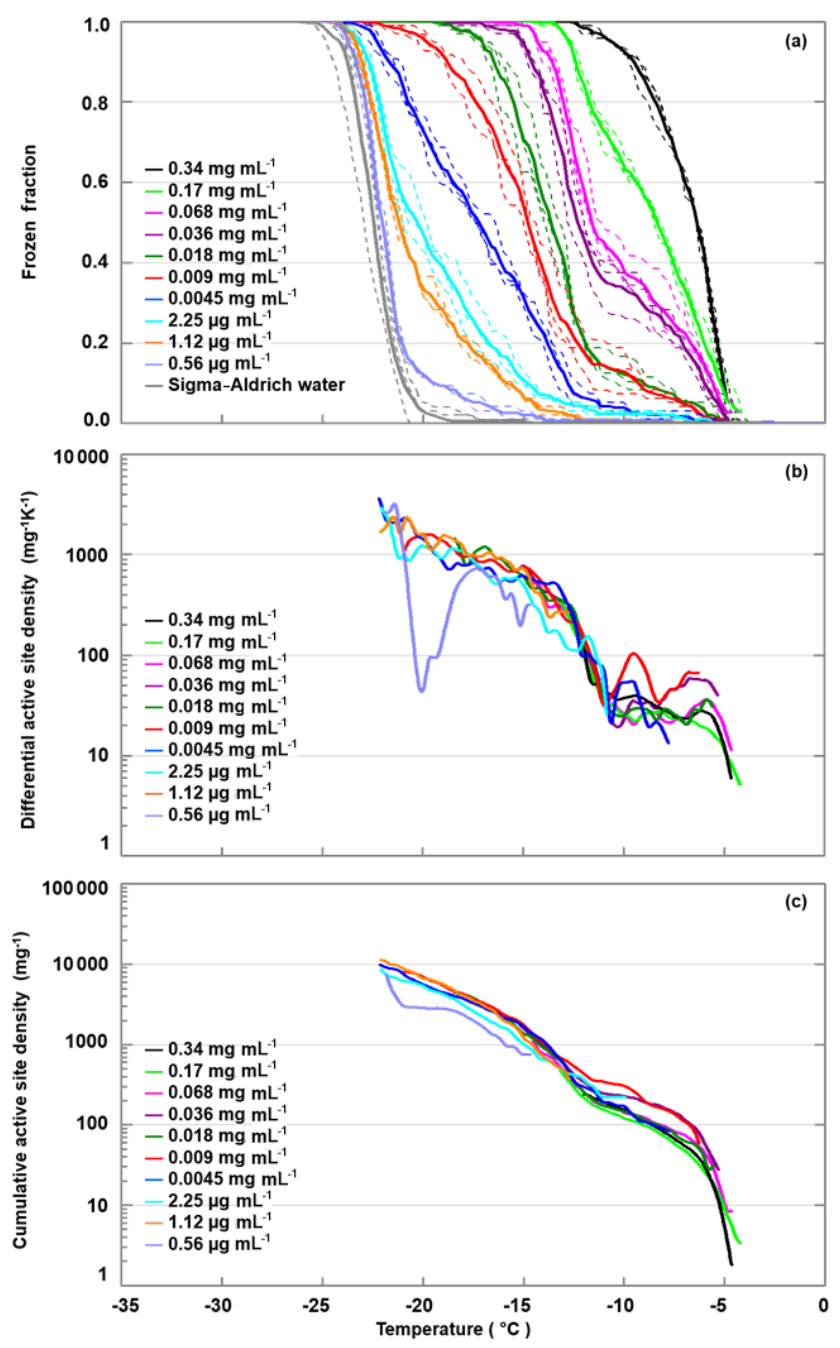

Figure 6. Freezing experiments with an apoferritin (batch 2) dilution series. (a) Fraction of droplets frozen as a function of temperature for concentrations between $0.34 \mathrm{mg} \mathrm{mL}^{-1}$ and $0.56 \mu \mathrm{g} \mathrm{mL}^{-1}$. (b) Differential IN-active site densities per unit mass and kelvin calculated with Eq. (2). (c) Cumulative active site densities per unit mass calculated with Eq. (1).

maximum at $12.5 \pm 0.3 \mathrm{~nm}$ (taken as the average of the peak maxima from $0.34 \mathrm{mg} \mathrm{mL}^{-1}$ to $0.009 \mathrm{mg} \mathrm{mL}^{-1}$ ) agrees with the reported hydrodynamic diameter of the apoferritin cage of $12.7 \mathrm{~nm}$ (Petsev et al., 2000, 2001). This value confirms the presence of cage monomers as the dominant species. Nevertheless, the presence of cage dimers with a hydrodynamic diameter of $18.4 \mathrm{~nm}$ (Petsev et al., 2001) and trimers is also likely since these species would not be resolved from the monomers by DLS. According to Richter and Walker (1967), cage dimers, trimers, and oligomers are in dynamic equilibrium with cage monomers and become abundant at high solution concentrations $\left(>2 \mathrm{mg} \mathrm{mL}^{-1}\right)$. In addition, there is a fraction of oligomeric species that are stabilized by partial unfolding of some of the apoferritin subunits, which leads to the exposure of hydrophobic parts of the protein to the water environment, resulting in attraction between cage monomers instead of repulsion (Yang et al., 1994; Petsev, 2000; Petsev et al., 2000, 2001). These oligomers do not dissociate into cage monomers when the sample is diluted. Thomas et al. (1998) analysed horse spleen apoferritin as received from Sigma-Aldrich and also found other species in addition to monomers $(M \approx 440 \mathrm{kDa})$, dimers $(M \approx$ $880 \mathrm{kDa})$, and trimers $(M \approx 1300 \mathrm{kDa})$, namely, intermediate oligomers $(880 \mathrm{kDa}<M<1300 \mathrm{kDa})$, larger oligomers $(M>1300 \mathrm{kDa})$, intermediate aggregates $(\sim 10 \mathrm{mer}$ with $M \approx 5000 \mathrm{kDa})$, large aggregates (180mer with $M \approx$ $80 \mathrm{MDa}$ ), free subunits with $M<67 \mathrm{kDa}$, and also some lowmolecular-weight species with $M \approx 14$ and $6 \mathrm{kDa}$ likely due to proteolysis.

As shown in Fig. 8a, the monomer peak maximum is constant within error for concentrations down to $0.009 \mathrm{mg} \mathrm{mL}^{-1}$, but it significantly drops to $8.9 \pm 1.3 \mathrm{~nm}$ for the lowest concentration that could be investigated with DLS $\left(0.0045 \mathrm{mg} \mathrm{mL}^{-1}\right)$. The decrease in size is likely due to the dissociation of cage monomers into subunits. The maximum at $8.9 \mathrm{~nm}$ points to subunit hexamers (quarter cages) or subunit dodecamers (half cages); yet the presence of subunit dimers and whole cage monomers is also likely. Indeed, with high-resolution electron microscopy, Massover (1980) detected small objects below the size of cage monomers when the ferritin concentration was less than $0.01 \mu \mathrm{g} \mathrm{mL}^{-1}$ in agreement with a dynamic equilibrium between ferritin dissociation and association. It can be assumed that upon further dilution, this dissociation progresses until subunits, mostly dimers, prevail (Massover, 1980, 1993).

Figure $8 \mathrm{~b}$ displays the volume fraction of aggregates as a function of solution concentration by summing over the diameter range from 68 to $10^{4} \mathrm{~nm}$ of the DLS volume-weighted distribution. It shows that the ratio between monomericoligomeric species and aggregates is not constant but shifts slightly to aggregates for intermediate concentrations from 0.036 to $0.009 \mathrm{mg} \mathrm{mL}^{-1}$. This shift brings about a slight increase in aggregate concentration when the apoferritin concentration is decreased from 0.068 to $0.036 \mathrm{mg} \mathrm{mL}^{-1}$ (see Fig. 8c). A reason for the increased aggregation might be that we diluted the original apoferritin solution in $\mathrm{NaCl}$ with pure water. Since aggregation depends on repulsion between apoferritin cages which is influenced by the presence of electrolytes (Petsev, 2000; Petsev et al., 2000, 2001; Manciu and Ruckenstein, 2002), dilution could have promoted aggregation. The solutions with increased concentrations of aggregates $\left(0.036\right.$ to $\left.0.009 \mathrm{mg} \mathrm{mL}^{-1}\right)$ show at the same time the largest variability of aggregate concentration between measurements (note error bar lengths in Fig. 8b and c).

The shift to cage aggregates (cage multimers) correlates with the slightly increased active site densities in the temperature range from -4 to $-11^{\circ} \mathrm{C}$ observed for these concentrations in the freezing experiments (see Fig. $6 \mathrm{~b}$ and c). We take this as evidence that ice nucleation in the temperature range 


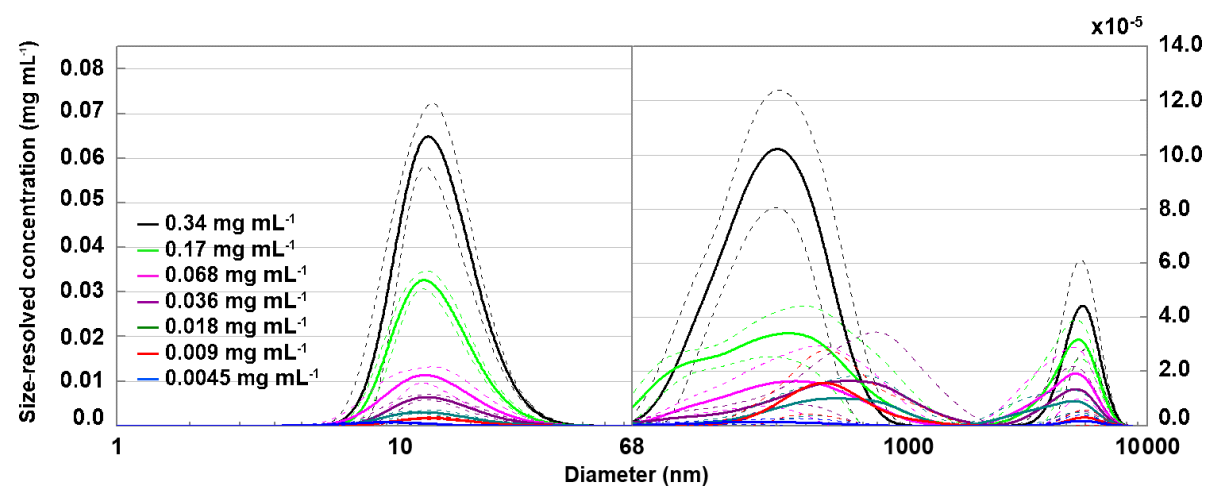

Figure 7. Hydrodynamic diameter of apoferritin (batch 2) depending on solution concentration measured with DLS with concentrations listed in the legend. Size-resolved concentrations are obtained by multiplying the volume-weighted distribution with the apoferritin concentration. The main peak at $12.5 \pm 0.3 \mathrm{~nm}$ corresponds to cage monomers and cage oligomers. The weak peaks above $68 \mathrm{~nm}$ (note the different $y$-axis scale) arise from cage aggregates. Solid lines are averages of multiple measurements, and dashed lines indicate 1 standard deviation.

between -4 and $-11{ }^{\circ} \mathrm{C}$ stems from active sites on aggregates. Since the loss of IN activity between -11 and $-21^{\circ} \mathrm{C}$ starts at $0.009 \mathrm{mg} \mathrm{mL}^{-1}$ and goes along with the decrease in monomeric-oligomeric species, we consider sites on cage monomers or oligomers to be responsible for ice nucleation in this temperature range. This evidences the importance of the protein assembly for IN activity and the relevance of aggregation to reach high freezing temperatures. In the following, the role of protein assembly will be further elucidated by disassembly-reassembly experiments.

\subsubsection{Apoferritin disassembly-reassembly}

Apoferritin cages have been shown to disassemble below $\mathrm{pH} 3$ into subunit dimers and reassemble within 10 to $40 \mathrm{~min}$ when $\mathrm{pH}$ is raised again to $4-8$, as illustrated in Fig. 9c (Gerl and Jaenicke, 1987, 1988; Smith-Johannsen and Drysdale, 1969; Linder et al., 1989). To further investigate which apoferritin species are relevant for IN activity, disassembly-reassembly experiments were carried out for two different apoferritin concentrations. Figure 9a shows the frozen fraction as a function of temperature for apoferritin, batch $2,0.036 \mathrm{mg} \mathrm{mL}^{-1}$. Due to cage disassembly at $\mathrm{pH} 2$, the freezing temperature decreases by about $2^{\circ} \mathrm{C}$ in the temperature range from -11 to $-21^{\circ} \mathrm{C}$, but only by about $0.5^{\circ} \mathrm{C}$ close to the freezing onset at about $-5^{\circ} \mathrm{C}$. Cage reassembly at $\mathrm{pH} 8$ fully restores the IN activity between -11 and $-21^{\circ} \mathrm{C}$ but induces hardly any increase between -4 and $-11^{\circ} \mathrm{C}$. Similarly, the experiments performed at lower concentration $\left(0.018 \mathrm{mg} \mathrm{mL}^{-1}\right.$, Fig. $\left.9 \mathrm{~b}\right)$ show a reversible decrease in IN activity between -11 and $-21^{\circ} \mathrm{C}$ and no decrease between -4 and $-11^{\circ} \mathrm{C}$ at $\mathrm{pH} 2$.

To identify the species present after disassembly at $\mathrm{pH} 2$, DLS measurements of the $\mathrm{pH} 2$ buffered apoferritin solutions were performed. Figure 10 presents the volume-weighted distribution of apoferritin (batch 2) with $0.036 \mathrm{mg} \mathrm{mL}^{-1}$ (panel a) and $0.018 \mathrm{mg} \mathrm{mL}^{-1}$ (panel b) for the directly pre- pared solutions and the disassembled ones at $\mathrm{pH} 2$. For $0.036 \mathrm{mg} \mathrm{mL}^{-1}$ the cage disassembly appears in the DLS measurements as a shift of the main peak from $12.6 \pm 0.8$ to $5.8 \pm 1.3 \mathrm{~nm}$. For $0.018 \mathrm{mg} \mathrm{mL}^{-1}$ the main peak shifts from $12.0 \pm 1.0 \mathrm{~nm}$ at neutral conditions to $6.8 \pm 1.7 \mathrm{~nm}$ at $\mathrm{pH} 2$. A diameter of about $6.5 \mathrm{~nm}$ corresponds to subunit dimers (Kim et al., 2011). The broad peak width indicates the presence of a wide distribution of subunit species up to cage monomers and possibly even cage dimers and cage trimers. The aggregate peaks show large variations between replicate measurements.

Considering the large standard deviations, there is no clear difference in aggregate volume fraction between directly prepared and disassembled samples for both investigated concentrations. These results confirm that cage monomers or small cage oligomers are responsible for the heterogeneous freezing observed between -11 and $-21^{\circ} \mathrm{C}$ and cage aggregates for freezing between -4 and $-11^{\circ} \mathrm{C}$.

\subsubsection{Ferritin species present in solution}

To further substantiate that aggregates are responsible for the IN activity of ferritin and apoferritin above $-11^{\circ} \mathrm{C}$, we performed DLS measurements with ferritin, batch 2 , concentrations of 0.04 and $0.39 \mathrm{mg} \mathrm{mL}^{-1}$. For these solution concentrations, the freezing experiments featured freezing onset temperatures of -10 and $-8{ }^{\circ} \mathrm{C}$ (see Fig. 3). The volumeweighted size distributions shown in Fig. 11 disclose an aggregate peak above $1000 \mathrm{~nm}$ but lack the aggregate peak below $1000 \mathrm{~nm}$, which is present in the DLS measurements performed with apoferritin. This suggests that aggregates with sizes below $1000 \mathrm{~nm}$ are relevant for the IN activity of ferritin and apoferritin above $-11^{\circ} \mathrm{C}$. These findings support our interpretation that apoferritin cage aggregates are responsible for freezing between -4 and $-11^{\circ} \mathrm{C}$, while cage monomers and small cage oligomers are relevant for IN activity below $-11^{\circ} \mathrm{C}$. To test how stable aggregates are and whether active 

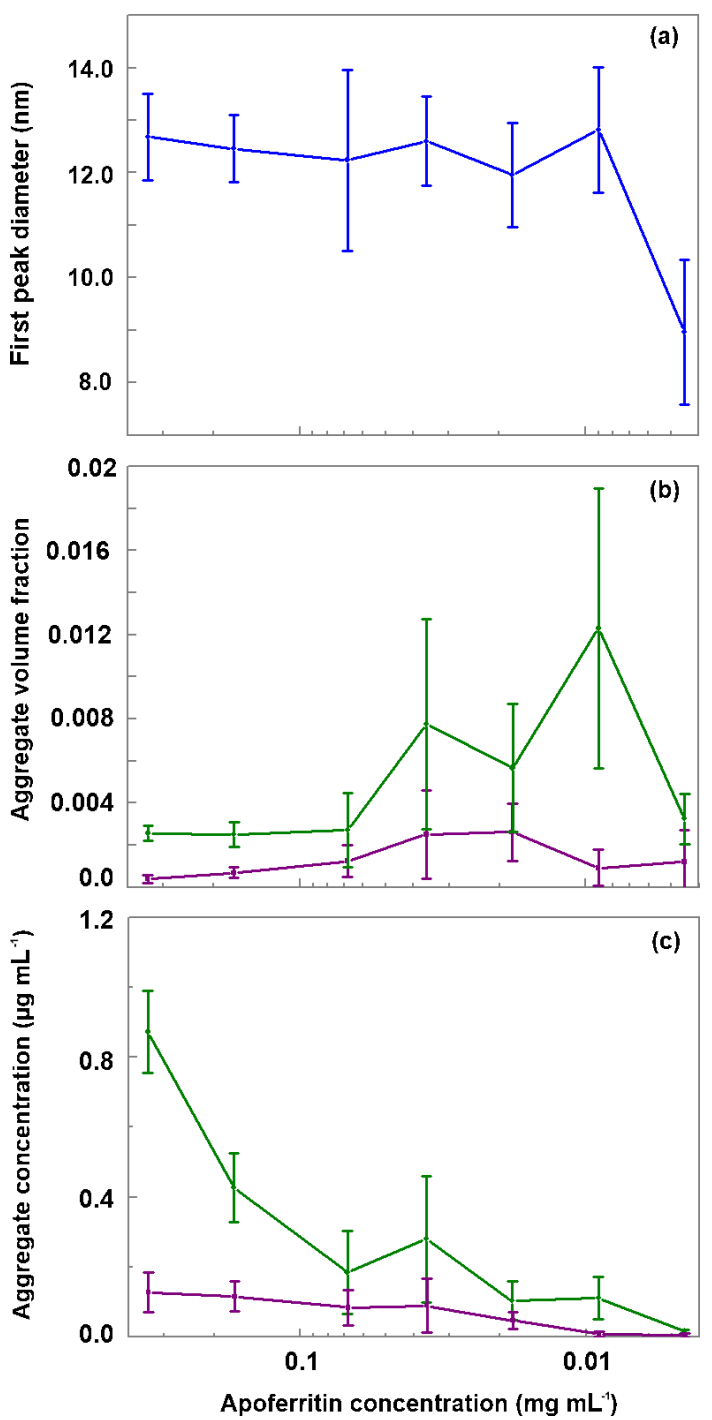

Figure 8. Evaluation of DLS measurements. (a) Hydrodynamic diameter of the main peak detected by DLS vs apoferritin solution concentration. (b) Relative abundance of aggregates (obtained by summing the volume-weighted distribution from 68 to $10^{4} \mathrm{~nm}$ ). (c) Absolute concentration of aggregates in the solution (obtained by multiplying the aggregate volume-weighted distribution with the apoferritin solution concentration). Green lines in panels $b$ and $c$ represent aggregates from 68 to $1990 \mathrm{~nm}$ while purple lines represent aggregates from 2300 to $10^{4} \mathrm{~nm}$. The vertical bars indicate one standard deviation.

sites persist during freeze-thaw cycles, we performed the following refreeze experiments.

\subsubsection{Refreeze experiments}

We repeated freeze-thaw cycles in refreeze experiments with the same filling of the 96-well tray for three different apoferritin concentrations (batch 2, 0.34, 0.036, and $0.018 \mathrm{mg} \mathrm{mL}^{-1}$ ). For each concentration we prepared three independent fillings, and for each filling we performed a first freeze-thaw cycle followed by four refreeze cycles. Figure 12 shows the frozen fraction as a function of temperature in the top three rows and the evolution of the frozen fraction for selected temperatures $\left(-5,-10,-15\right.$, and $\left.-20^{\circ} \mathrm{C}\right)$ with an increasing number of freeze-thaw cycles (bottom row). While the frozen fraction at $-5^{\circ} \mathrm{C}$ slightly increased with the increasing number of freeze-thaw cycles, it rather decreased for $T=-15$ and $-20^{\circ} \mathrm{C}$. This indicates that additional aggregate sites emerge with an increasing number of freezethaw cycles (or increasing time in water), while monomericoligomeric sites tend to disappear. For the highest investigated concentration $\left(0.34 \mathrm{mg} \mathrm{mL}^{-1}\right)$ almost all wells froze in the temperature range from -4 to $-11^{\circ} \mathrm{C}$ due to active sites on aggregates. For the two lower concentrations $(0.036$ and $0.018 \mathrm{mg} \mathrm{mL}^{-1}$ ) some wells froze between -4 and $-11^{\circ} \mathrm{C}$ while the majority froze in the temperature range indicative for monomeric or oligomeric sites $\left(-11\right.$ to $\left.-21{ }^{\circ} \mathrm{C}\right)$. Note that the freezing events at the lowest temperatures (below $-21^{\circ} \mathrm{C}$ ) might also arise from random impurities present in SA water.

To assess the stability of active sites, we analysed the refreeze experiments on a well-by-well basis. Figure 13 displays the freezing temperatures per well for the second refreeze experiment with an apoferritin concentration of $0.036 \mathrm{mg} \mathrm{mL}^{-1}$ (similar plots for the other experiments are shown in Fig. S5). A detailed analysis of all refreeze experiments carried out with 0.036 and $0.018 \mathrm{mg} \mathrm{mL}^{-1}$ apoferritin is presented in Tables 2 and 3, respectively. For the three refreeze experiments performed with $0.036 \mathrm{mg} \mathrm{mL}^{-1}$ apoferritin samples, FF at $-11{ }^{\circ} \mathrm{C}$ (averaged over all 96 wells and the five cycles) was 0.219 for the first experiment (i.e. 29 wells were frozen at $-11^{\circ} \mathrm{C}$ in the first cycle, 19 in the second, 20 in the third, 17 in the fourth, and 20 in the fifth, yielding $(29+19+20+17+20) /(5 \times 96)=0.219), 0.304$ for the second experiment, and 0.319 for the third experiment. Assuming that freezing temperatures are stochastic without any dependence on the specific well, the probability that a well constantly froze at $T>-11^{\circ} \mathrm{C}$ is therefore $0.002-0.01$ $\left(0.219^{4}\right.$ to $\left.0.319^{4}\right)$. Thus, the fraction of wells that always froze at $T>-11^{\circ} \mathrm{C}$ should be $0.002-0.01$. However, evaluation of the well-by-well results (shown in Figs. 13 and S5) yielded fractions of wells always freezing at $T>-11^{\circ} \mathrm{C}$ from 0.156 (i.e. in the first experiment, 15 out of the 96 wells froze above $-11^{\circ} \mathrm{C}$ during all five cycles) to 0.271 (see Table 2), indicating that freezing sites on aggregates tend to persist over several freeze-thaw cycles. Similar conclusions can be drawn from refreeze experiments performed with apoferritin concentrations of $0.018 \mathrm{mg} \mathrm{mL}^{-1}$ with $\mathrm{FF}$ at $-11^{\circ} \mathrm{C}$ of $0.129,0.150$, and 1.65. Assuming, again, the random occurrence of freezing, the probability that a well always froze above $-11^{\circ} \mathrm{C}$ would equal $0.0003-0.0007\left(0.129^{4}\right.$ to $\left.1.65^{4}\right)$, implying that no well should freeze constantly above $-11^{\circ} \mathrm{C}$. Nevertheless, we found a fraction of 0.083 to 0.146 (see Table 3). On the other hand, freezing events of some 


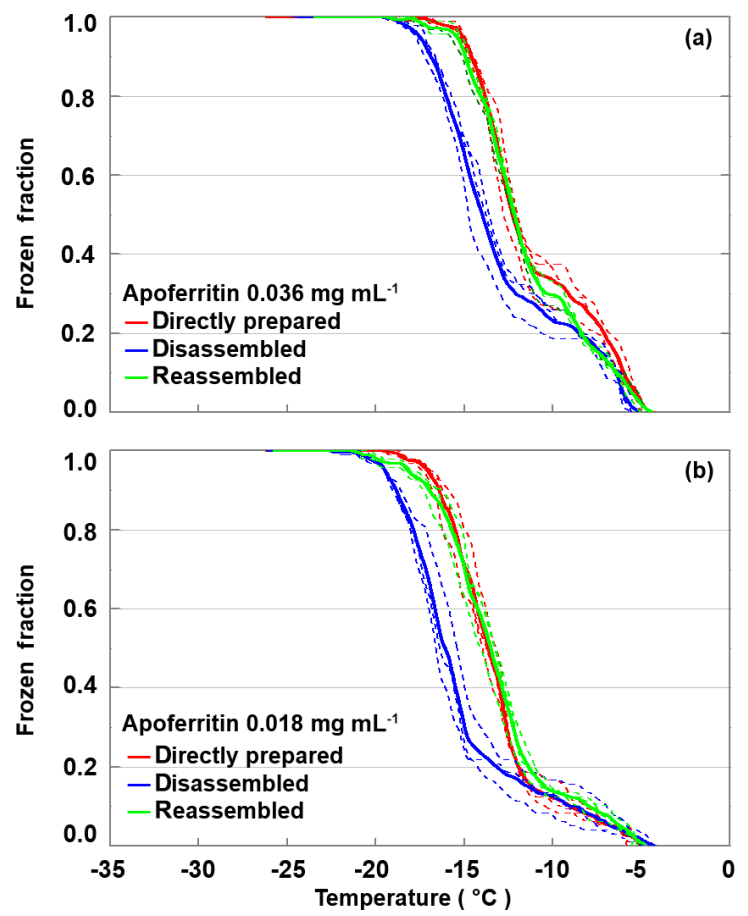

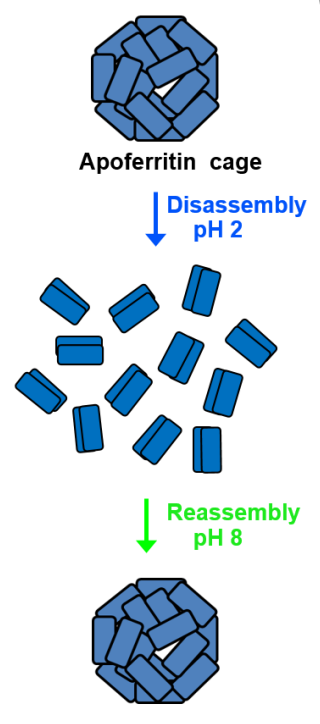

Apoferritin subunit

(c)

Figure 9. Disassembly and reassembly experiment performed with apoferritin (batch 2) at $0.036 \mathrm{mg} \mathrm{mL}^{-1}$ (a) and $0.018 \mathrm{mg} \mathrm{mL}^{-1}$ (b). Frozen fractions are given for the directly prepared apoferritin, the disassembled apoferritin at $\mathrm{pH} 2$, and the reassembled apoferritin at $\mathrm{pH} 8$. (c) Schematic illustration of the disassembly and reassembly process: at $\mathrm{pH} 2$ apoferritin undergoes disassembly into rod-like subunit dimers, and increasing $\mathrm{pH}$ to 8 restores the fully assembled apoferritin cage.

wells span temperature ranges of over $15^{\circ} \mathrm{C}$, indicating that some aggregate active sites appeared or disappeared over a sequence of five freeze-thaw cycles. Overall, the spread of freezing temperature between freeze-thaw cycles of one well is distinctly smaller than the spread over the whole plate, indicating that ice nucleation does not occur on frequent apoferritin sites each with a low IN probability but on a few sites that induce freezing with a high probability and persist over several freeze-thaw cycles.

\subsection{Comparison with other ice-nucleating proteins}

Section 3.1 revealed IN activity of all screened proteins and the virus. This outcome is astonishing, considering that so far IN activity has only been found in some bacteria, yeasts, lichen, and fungi, which express IN-active proteins tailored for the purpose to nucleate ice. Instead, the investigated proteins have very diverse functions, which are not ice nucleation.

The IN activity of the ice-nucleating protein expressed by $P$. syringae deteriorates outside the $\mathrm{pH}$ range from 6 to 8 and decreases by about $6^{\circ} \mathrm{C}$ after a 10 min heat treatment at $40^{\circ} \mathrm{C}$ (Pouleur et al., 1992). In contrast, the IN activity of apoferritin and ferritin showed little variation from $\mathrm{pH} 1$ to 9 and was also heat resistant. This insensitivity to heat and $\mathrm{pH}$ resembles that of the IN-active fungal species Fusarium avenaceum, which persists up to $-2.5^{\circ} \mathrm{C}$ and is also of proteinaceous nature. IN activity of $F$. avenaceum remains constant from $\mathrm{pH} 1$ to 13 and proves heat tolerance up to $60^{\circ} \mathrm{C}$ (Pouleur et al., 1992). Moreover, it is preserved after passing through a $0.22 \mu \mathrm{m}$ pore-size filter, indicating that the IN-active proteins are not bound to a cell membrane (Pouleur et al., 1992).

Using radiation inactivation analysis, Govindarajan and Lindow (1988) found a minimum mass of $150 \mathrm{kDa}$ for INactive sites of $P$. syringae with activity at -12 to $-13^{\circ} \mathrm{C}$, in agreement with the apparent mass of the IN-active proteins expressed by P. syringae (Lindow et al., 1989). Apoferritin cage monomers $(\sim 480 \mathrm{kDa})$, cage dimers $(\sim 960 \mathrm{kDa})$, and cage trimers $(\sim 1440 \mathrm{kDa})$ with activity between -11 and $-21^{\circ} \mathrm{C}$ exhibit masses $3-9$ times larger, indicating that the apoferritin structure is less optimized for ice nucleation than the one of the ice-nucleating protein of $P$. syringae. For IN activity at $-2{ }^{\circ} \mathrm{C}$, Govindarajan and Lindow (1988) determined a mass of $19000 \mathrm{kDa}$, arising through aggregation of the proteins on the outer membrane of intact cells (Yankofsky et al., 1981). Qiu et al. (2019) also found that aggregation increased the ability of ice-binding proteins to induce ice nucleation. This is consistent with our finding that aggregates are responsible for the IN activity at higher temperatures. Despite their low molecular masses ranging from 10 to $67 \mathrm{kDa}$, all the proteins screened in this study were able to induce freezing up to at least $-8^{\circ} \mathrm{C}$. This hints to oligomers 


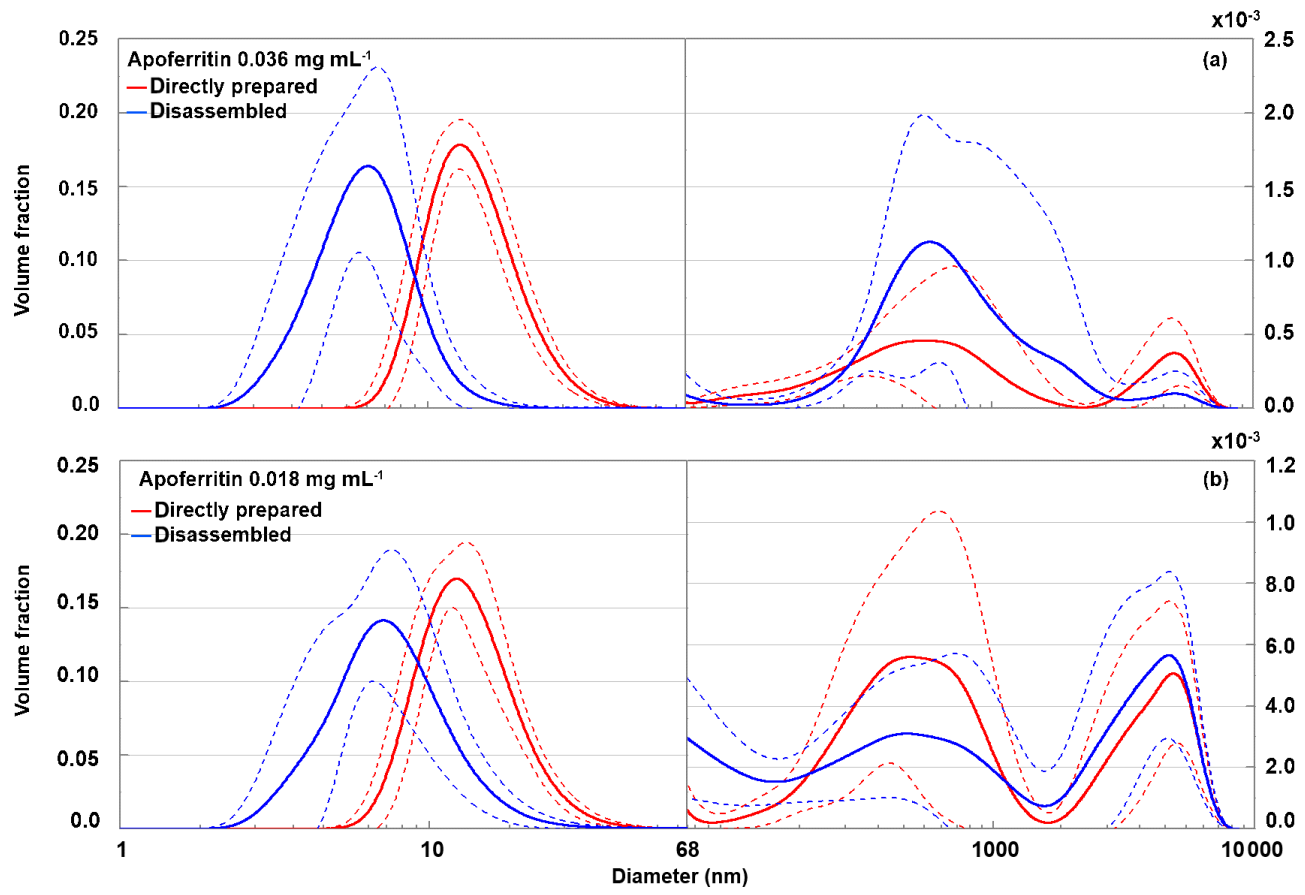

Figure 10. Volume-weighted distribution of directly prepared (red) and disassembled (blue) apoferritin, batch 2, with concentrations of $0.036 \mathrm{mg} \mathrm{mL}^{-1}$ (a) and $0.018 \mathrm{mg} \mathrm{mL}^{-1}$ (b). Solid lines are averages of multiple measurements, and dashed lines indicate 1 standard deviation.

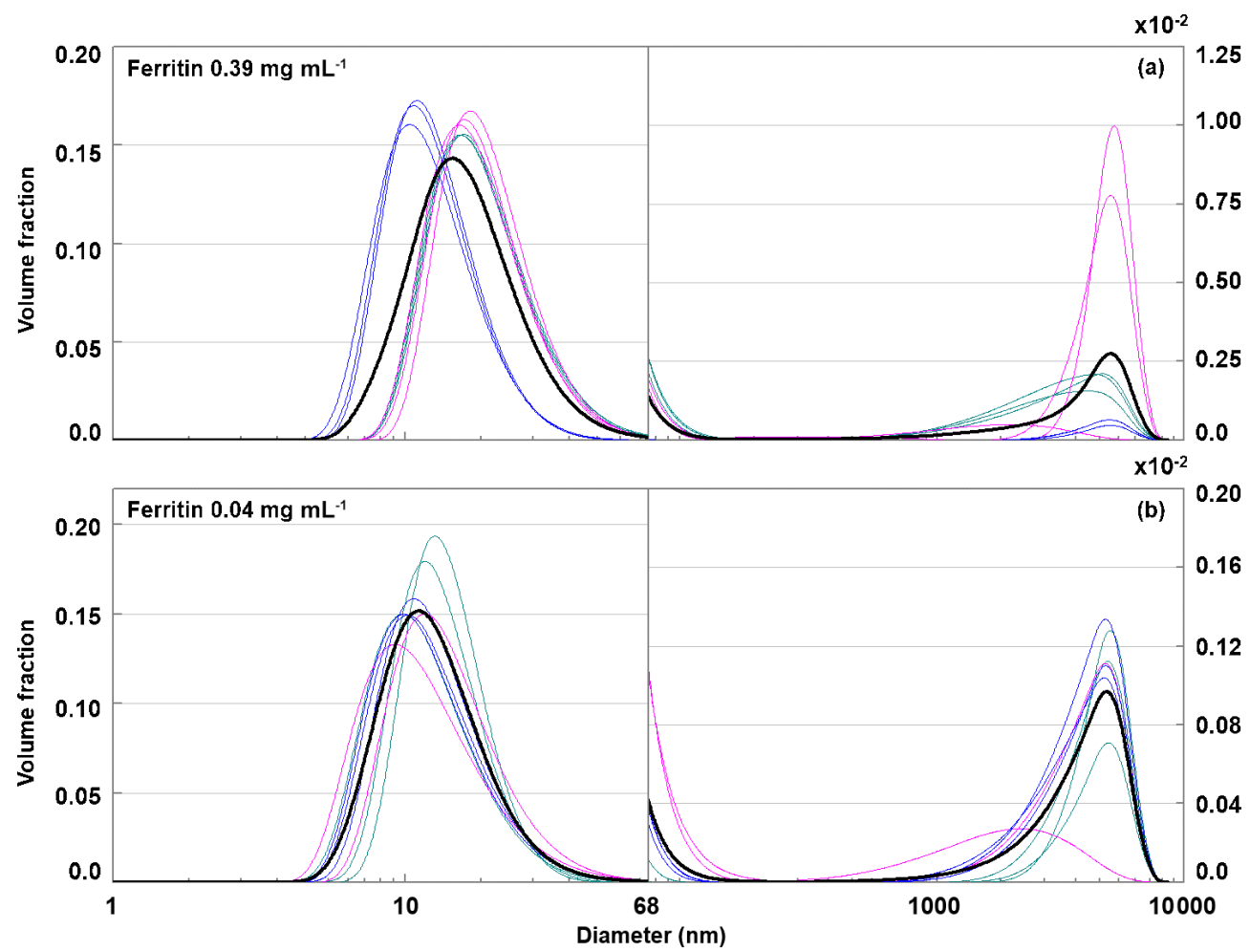

Figure 11. Volume-weighted distribution of ferritin with concentrations of $0.39 \mathrm{mg} \mathrm{mL}^{-1}$ (a) and $0.04 \mathrm{mg} \mathrm{mL}^{-1}$ (b). Green, pink, and blue lines correspond to single measurements performed with three different preparations. The black line gives the average of all measurements. 

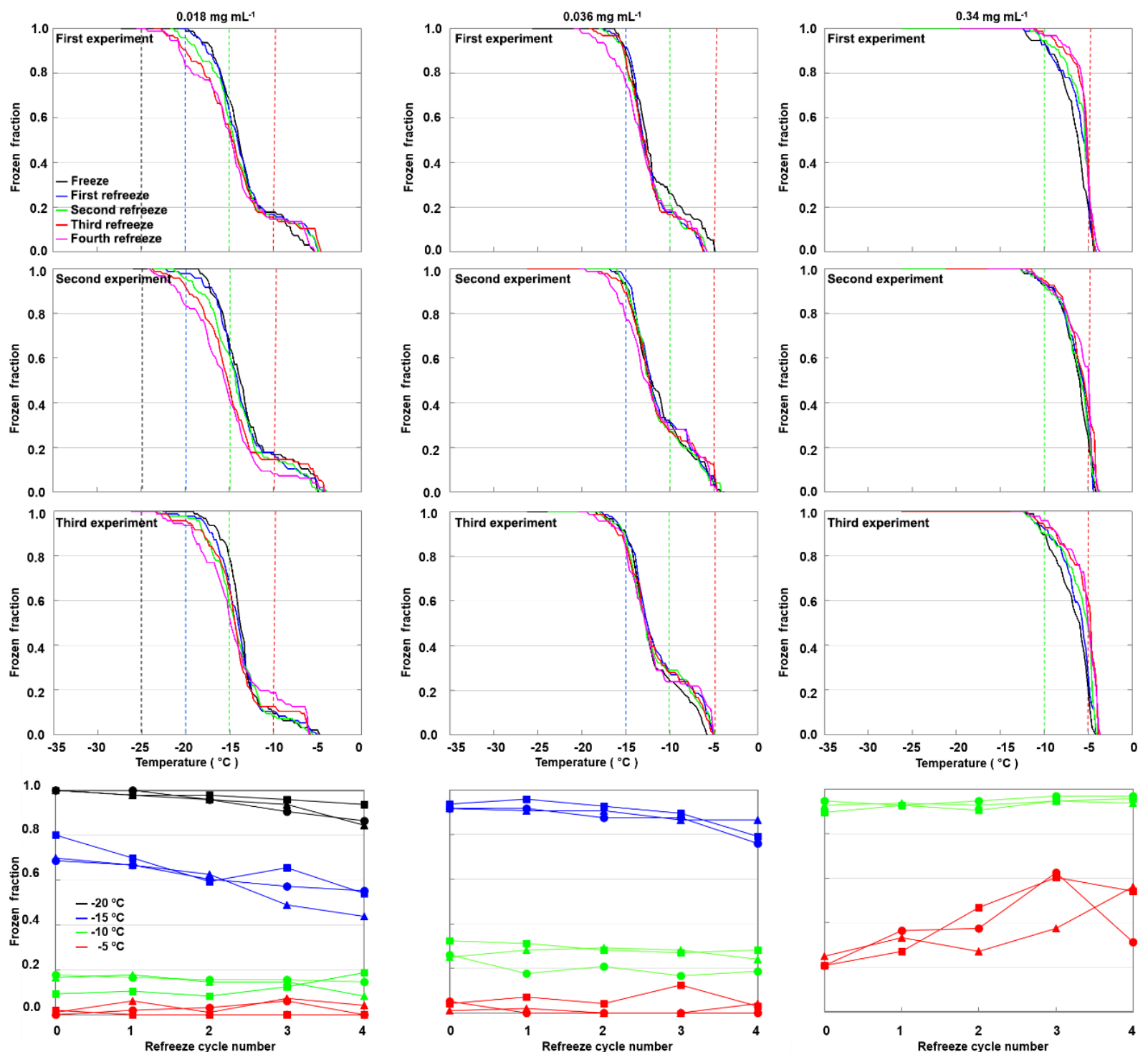

Figure 12. Refreeze experiments with apoferritin (batch 2) solutions with concentrations of $0.018 \mathrm{mg} \mathrm{mL}^{-1}$ (first column), $0.036 \mathrm{mg} \mathrm{mL}^{-1}$ (second column), and $0.34 \mathrm{mg} \mathrm{mL}^{-1}$ (third column). Frozen fractions are given for the first freeze-thaw cycle (cycle 0 ) and four refreeze cycles. For each concentration three independent preparations were investigated (rows 1-3). Experiments were analysed with respect to the frozen fraction at $-5,-10,-15$, and $-20^{\circ} \mathrm{C}$ (row 4 ).

Table 2. Freezing statistics of refreeze experiments performed with apoferritin solutions, batch $2,0.036 \mathrm{mg} \mathrm{mL}^{-1}$.

\begin{tabular}{lrrr}
\hline & First experiment & Second experiment & Third experiment \\
\hline Freezing temperature range over all wells and all cycles & -5.1 to $-20.4^{\circ} \mathrm{C}$ & -5.1 to $-19.5^{\circ} \mathrm{C}$ & -4.3 to $-19.7^{\circ} \mathrm{C}$ \\
Smallest freezing range of a well over all cycles & -8.8 to $-9.7^{\circ} \mathrm{C}$ & -12.7 to $-13.4^{\circ} \mathrm{C}$ & -11.8 to $-12.2^{\circ} \mathrm{C}$ \\
Largest freezing range of a well over all cycles & -6.5 to $-17.0^{\circ} \mathrm{C}$ & -5.6 to $-18.8^{\circ} \mathrm{C}$ & -5.1 to $-16.1^{\circ} \mathrm{C}$ \\
Average freezing temperature of all wells over all cycles & $-12.5^{\circ} \mathrm{C}$ & $-11.9^{\circ} \mathrm{C}$ & $-11.5^{\circ} \mathrm{C}$ \\
Highest freezing temperature of a well over all cycles & $-6.6^{\circ} \mathrm{C}$ & $-5.5^{\circ} \mathrm{C}$ & $-4.9^{\circ} \mathrm{C}$ \\
Coldest freezing temperature of a well over all cycles & $-17.5^{\circ} \mathrm{C}$ & $-17.4^{\circ} \mathrm{C}$ & $-16.9^{\circ} \mathrm{C}$ \\
Frozen fraction at $T=-11^{\circ} \mathrm{C}$ & 0.219 & 0.304 & 0.329 \\
Fraction of wells always frozen at $T=-11^{\circ} \mathrm{C}$ & 0.156 & 0.219 & 0.271 \\
\hline
\end{tabular}




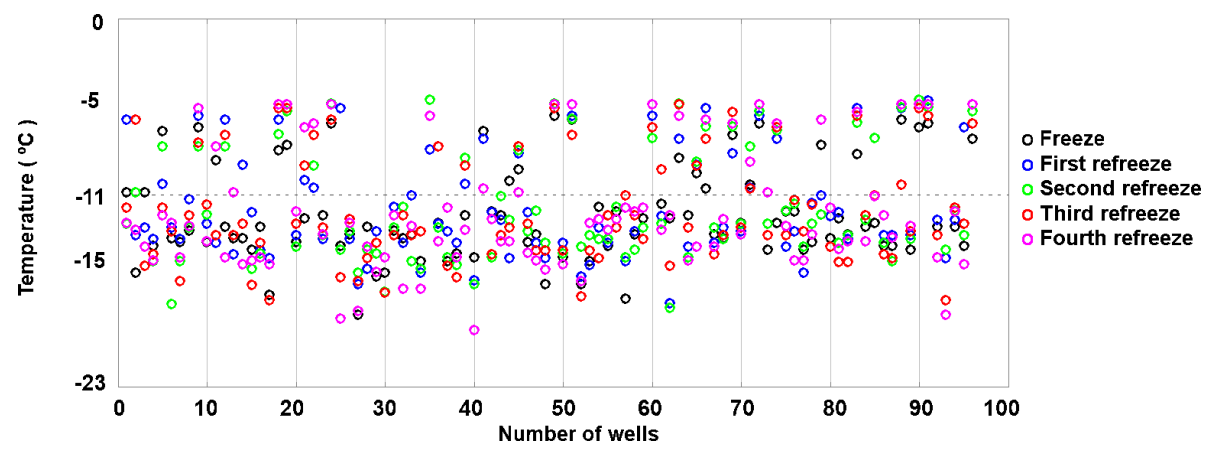

Figure 13. Well-by-well results of a refreeze experiment performed with apoferritin (batch 2), second experiment with $0.036 \mathrm{mg} \mathrm{mL}^{-1}$ of Fig. 12.

Table 3. Freezing statistics of refreeze experiments performed with apoferritin solutions, batch $2,0.018 \mathrm{mg} \mathrm{mL}^{-1}$.

\begin{tabular}{lrrr}
\hline & First experiment & Second experiment & Third experiment \\
\hline Freezing temperature range over all wells and all cycles & -4.8 to $-24.5^{\circ} \mathrm{C}$ & -4.1 to $-24.0^{\circ} \mathrm{C}$ & -5.0 to $-23.5^{\circ} \mathrm{C}$ \\
Smallest freezing range of a well over all cycles & -16.6 to $-17.1^{\circ} \mathrm{C}$ & -12.0 to $-12.7^{\circ} \mathrm{C}$ & -18.3 to $-19.3^{\circ} \mathrm{C}$ \\
Largest freezing range of a well over all cycles & -8.6 to $-22.8^{\circ} \mathrm{C}$ & -5.3 to $-21.4^{\circ} \mathrm{C}$ & -6.5 to $-17.3^{\circ} \mathrm{C}$ \\
Average freezing temperature of all wells over all cycles & $-14.0^{\circ} \mathrm{C}$ & $-14.2^{\circ} \mathrm{C}$ & $-14.2^{\circ} \mathrm{C}$ \\
Highest freezing temperature of a well over all cycles & $-5.5^{\circ} \mathrm{C}$ & $-4.1^{\circ} \mathrm{C}$ & $-6.5^{\circ} \mathrm{C}$ \\
Coldest freezing temperature of a well over all cycles & $-19.9^{\circ} \mathrm{C}$ & $-19.9^{\circ} \mathrm{C}$ & $-22.1^{\circ} \mathrm{C}$ \\
Frozen fraction at $T=-11^{\circ} \mathrm{C}$ & 0.165 & 0.150 & 0.129 \\
Fraction of wells always frozen at $T=-11^{\circ} \mathrm{C}$ & 0.146 & 0.094 & 0.083 \\
\hline
\end{tabular}

or aggregates of these proteins as the IN-active species. Indeed, casein, which is known to form micelles (Dalgleish and Corredig, 2012) consistently induced freezing at high temperatures (from -8 to $-13^{\circ} \mathrm{C}$ ). In contrast, the hydrophobins (HPA and HPB), which form monolayer coatings on surfaces rather than aggregates, exhibit only a small fraction of sites that are active between -6 and $-8^{\circ} \mathrm{C}$. The ice-binding protein LeIBP with only a few nucleation events above $-10^{\circ} \mathrm{C}$ is known to dimerize in solution (Lee et al., 2012), but might have a low tendency to form larger aggregates.

The apoferritin dilution series covers the range from highly IN active at $0.34 \mathrm{mg} \mathrm{mL}^{-1}$ to similarly IN active as pure water at $0.56 \mu \mathrm{gLL}^{-1}$. Given a sample volume of $50 \mu \mathrm{L}$, the number of apoferritin cages ranges from $2.1 \times 10^{13}$ to $3.5 \times 10^{10}$ per well, indicating that IN activity is limited to a tiny fraction of the monomeric-oligomeric species and probably to only a minority of aggregates. In the case of $P$. syringae the fraction of IN-active cells strongly varies, but it is clearly higher than the number of IN-active sites in apoferritin. Depending on cultivation, every tenth cell to one cell in a million show IN activity at -2 to $-4{ }^{\circ} \mathrm{C}$ (Després et al., 2012; Murray et al., 2012). Snomax ${ }^{\circledR}$, a commercial product containing IN-active proteins from non-viable $P$. syringae, exhibits active site densities increasing from $10^{4}$ to $10^{9} \mathrm{mg}^{-1}$ for temperatures decreasing from -5 to $-10^{\circ} \mathrm{C}$ (Wex et al., 2015; Kanji et al., 2017). In comparison, the apoferritin active site density per mass is small, ranging from $1 \mathrm{mg}^{-1}$ at $-5^{\circ} \mathrm{C}$ to $100 \mathrm{mg}^{-1}$ at $-10{ }^{\circ} \mathrm{C}$, again pointing to a low density of IN-active sites occurring accidentally on apoferritin. Interestingly, the IN activity of Snomax ${ }^{\circledR}$ decreases with storage time, indicating that the most efficient nucleation sites of Snomax ${ }^{\circledR}$ degrade with time (Polen et al., 2016; Häusler et al., 2018). This may be due to loss of free hydrogen bonding sites or disintegration of larger aggregates.

Ice-nucleating proteins expressed by Pseudomonas contain a central domain, composed of 50-80 repeats of 16 amino acids with the sequence GYGSTxTAxxxSxLxA where $x$ can be any amino acid. The repetition of this sequence is considered to provide the ice-templating sites (Ling et al., 2018; Wolber, 1993; Schmid et al., 1997) by binding water molecules to the threonine-x-threonine (TxT) motif of this sequence, and thus aligning water molecules into a favourable pattern for the formation of an ice embryo (Garnham et al., 2011; Graether and Jia, 2001). Apoferritin lacks repetition units containing the TxT motif (Andrews et al., 1992), showing that IN activity of proteins can also arise from other structures.

Recently, antifreeze and ice-binding proteins have proven to be IN active when they aggregate to larger structures, which was explained by ice-nucleating sites that emerge when ice-binding sites are repeated in aggregated structures (Eickhoff et al., 2019; Hudait et al., 2018; Qiu et al., 2019). Nevertheless, the IN activity of the ice-binding protein LeIBP is only intermediate, compared with the other proteins 
screened in Sect. 3.1, although LeIBP exhibits a repetition sequence that allows it to bind to ice. Our finding of a general ability of proteins to nucleate ice indicates that a repetition section matching the ice structure is not a prerequisite for IN activity in proteins.

In a recent study, Pandey et al. (2016) demonstrated by sum frequency generation (SFG) spectroscopy and molecular dynamics simulations that the ice-active sites of $P$. syringae feature hydrophilic-hydrophobic patterns that enhance ice nucleation. Moreover, time-resolved SFG spectroscopy showed that the protein facilitates the removal of latent heat from the nucleation site. Since the screened proteins all have characteristic freezing onset temperatures, their nucleation sites do not seem to be totally random but related to the protein structure. A templating effect may result from the pattern of hydrophilic and hydrophobic regions on alpha helices and beta sheets together with sites for hydrogen bonding responsible for the tertiary and quaternary structure. In misfolded proteins, these may be available to bind water molecules. Attached to ferritin are water molecules in intersubunit interfaces through hydrogen bonds (Hempstead et al., 1997), which may be a starting point for ice embryos. Also, the outer protein shell features iron bonding sites (Massover, 1993), which may play a role in ice nucleation. The refreeze experiments have shown that IN activity of apoferritin is localized at a few sites of high IN efficiency while the rest of the proteins are inactive. Our screening showed that such highly active sites seem to arise in proteins with very different functions. This indicates that protein structures have an inherent ability to nucleate ice that can be evoked through misfolding of the amino acid chains or through aggregation.

\subsection{Atmospheric implications}

Different common proteins, showed IN activity in DRINCZ experiments with freezing onsets above $-10^{\circ} \mathrm{C}$. This supports the potential relevance of biological INP for ice formation at mixed-phase cloud conditions. Ferritin and apoferritin, the largest among the investigated proteins showed IN activity up to $-4{ }^{\circ} \mathrm{C}$, yet with a low density of active sites.

Since ferritin is present in most organisms including bacteria, animals, and plants, it might well be released to the environment after the death of organisms when cells are disrupted. However, our measurements indicate that the IN activity disappears in highly diluted solutions, most probably because aggregated ferritin and apoferritin disintegrate and cages disassemble into subunits. Indeed, if aggregation were a prerequisite for ice nucleation in proteins, the effect of dilution might reduce the ice-nucleation potential of proteins in general. Moreover, different types of proteins will be mixed with each other and with organic and non-proteinaceous biological material, leading to mixed aggregates in aerosol particles. Therefore, in order to be of atmospheric relevance, mixed aggregates also need to have the ability to nucleate ice. While proteins may aggregate in aerosol particles, they need to be prevented from disintegrating when aerosol particles dilute during cloud droplet activation. Therefore, to stick together, they might need to adhere to a surface, e.g. the droplet surface or mineral surfaces. Mineral surfaces keeping proteins aggregated might explain findings that soil dust containing minerals together with biological material is able to nucleate ice at higher temperatures than dust aerosols from deserts (Pratt et al., 2009; Conen et al., 2011; O'Sullivan et al., 2014; Tobo et al., 2013, 2014; Augustin-Bauditz et al., 2016).

\section{Conclusions}

Freezing experiments performed with horse spleen ferritin and apoferritin reveals IN activity in two distinct temperature ranges, namely from -4 to -11 and from -11 to $-21^{\circ} \mathrm{C}$. We exposed the samples to different conditions to identify the nature of the IN-active entities.

- The strong reduction of freezing temperatures after combined acid and heat treatment indicates that proteinaceous species are responsible for the observed IN activity.

- The resistance of IN activity to heat treatment $(5 \mathrm{~h}$ at $110{ }^{\circ} \mathrm{C}$ ) corresponds to the high thermal stability of ferritin and apoferritin.

- At concentration below $0.56 \mu \mathrm{g} \mathrm{mL}^{-1}$ the frozen fraction of the horse spleen apoferritin sample reached similarly low values as the SA water background. At this concentration more than $10^{10}$ cage monomers are still present in each $50 \mu \mathrm{L}$ sample aliquot.

Taking these findings together, the IN activity seems to stem from proteinaceous species but not from the regularly folded cage monomers. Indeed, horse spleen apoferritin solutions also contain, apart from the dominating cage monomers, cage aggregates, misfolded cage monomers, and oligomeric species such as cage dimers and cage trimers. Correlating DLS measurements with freezing results indicates that ferritin and apoferritin aggregates are responsible for the IN activity between -4 and $-11^{\circ} \mathrm{C}$ and misfolded monomeric or oligomeric species between -11 and $-21^{\circ} \mathrm{C}$

Batch-to-batch variability of aggregate and oligomer concentrations may also explain the observed variation in FF between the investigated batches of ferritin and apoferritin. Moreover, the lower IN activity of ferritin compared to apoferritin suggests that the iron oxide plays no active role in the IN activity of ferritin.

The apoferritin results together with the screening experiments performed with different proteins indicate that IN activity is a common property of proteins most probably arising accidentally through favourable aggregation of single proteins (or single protein cages) into larger structures. However, it is questionable whether this accidental, proteinaceous IN 
activity is of relevance in the atmosphere for mixed-phase cloud glaciation, since protein aggregates can disintegrate due to dilution in cloud droplets. Yet, if proteins aggregated at droplet or mineral surfaces were IN active, this might provide an explanation for the IN activity of biological material and the superior IN activity of soil dust compared with mineral dust.

Data availability. The data in this article are available at the ETH repository: https://doi.org/10.3929/ethz-b-000391914 (Marcolli, 2020).

Supplement. The supplement related to this article is available online at: https://doi.org/10.5194/acp-20-3291-2020-supplement.

Author contributions. MCC conducted the ice-nucleation experiments. ROD introduced MCC to the instrument and supported her with the measurements. MCC, ROD, MAIA, AMB, and CM contributed to the planning and interpretation of the experiments. MAIA conducted the DLS measurements and prepared the figures. CM prepared the manuscript with contributions from MAIA, MCC, ROD, and AMB.

Competing interests. The authors declare that they have no conflict of interest.

Acknowledgements. We acknowledge the Swiss National Foundation for financial support (project numbers: IZSEZ0_179149/1 and 200021_156581). We are grateful for financial support from the Basque government (Elkartek programmes ng 15 and ng 17), and from the Spanish MINECO (MAT2013-46006-R grant, Red Temática de Excelencia en Física Virológica, Maria de Maeztu "Units of Excellence" programme MDM-2016-0618). We thank Ulrike Lohmann and Zamin Kanji for helping to initiate and support this project, Nadine Borduas-Dedekind and Julia Werz for sample preparation optimization and preliminary results, and María Isabel Asenjo Sanz (Centro de Física de Materiales) and Jorge Melillo (Centro de Física de Materiales, CIC nanoGUNE) for valuable discussions and assistance during the DLS measurements. We acknowledge Mitsuhiro Okuda, Zamin A. Kanji, and Nadine BorduasDedekind for helpful discussions. We thank Thomas Subkowski (White Biotechnology Research, BASF) for supplying the hydrophobins and Christina Wege from the University of Stuttgart for contributing the tobacco mosaic virus. We are especially thankful to Se Jong Han from the Korea Polar Research Institute (KOPRI) for providing the ice-binding protein LeIBP.

Financial support. This research has been supported by the Swiss National Foundation (grant nos. IZSEZ0_179149/1 and 200021_156581), the Basque government (Elkartek programmes ng 15 and ng 17), and the Spanish MINECO (grant no. MAT201346006-R, programme MDM-2016-0618).
Review statement. This paper was edited by Daniel Knopf and reviewed by two anonymous referees.

\section{References}

Abdelmonem, A., Backus, E. H. G., Hoffmann, N., Sánchez, M. A., Cyran, J. D., Kiselev, A., and Bonn, M.: Surface-charge-induced orientation of interfacial water suppresses heterogeneous ice nucleation on $\alpha$-alumina (0001), Atmos. Chem. Phys., 17, 78277837, https://doi.org/10.5194/acp-17-7827-2017, 2017.

Akila, M., Priyamvada, H., Ravikrishna, R., and Gunthe, S. S.: Characterization of bacterial diversity and ice-nucleating ability during different monsoon seasons over a southern tropical Indian region, Atmos. Environ., 191, 387-394, https://doi.org/10.1016/j.atmosenv.2018.08.026, 2018.

Aller, J. Y., Radway, J. C., Kilthau, W. P., Bothe, D. W., Wilson, T. W., Vaillancourt, R. D., Quinn, P. K., Coffman, D. J., Murray, B. J., and Knopf, D. A.: Size-resolved characterization of the polysaccharidic and proteinaceous components of sea spray aerosol, Atmos. Environ., 154, 331-347, https://doi.org/10.1016/j.atmosenv.2017.01.053, 2017.

Alonso, J. M., Górzny, M. L., and Bittner, A. M.: The physics of tobacco mosaic virus and virus-based devices in biotechnology, Trends Biotechnol., 31, 530-538, https://doi.org/10.1016/j.tibtech.2013.05.013, 2013.

Alpert, P. A., Aller, J. Y., and Knopf, D. A.: Initiation of the ice phase by marine biogenic surfaces in supersaturated gas and supercooled aqueous phases, Phys. Chem. Chem. Phys., 13, 19882-19894, https://doi.org/10.1039/C1CP21844A, 2011.

Andrews, S. C., Arosio, P., Bottke, W., Briat, J. F., von Darl, M., Harrison, P. M., Laulhère, J.-P., Levi, S., Lobreaux, S., and Yewdall, S. J.: Structure, function, and evolution of ferritins, J. Inorg. Biochem. 47, 161-174, https://doi.org/10.1016/01620134(92)84062-R, 1992.

Augustin-Bauditz, S., Wex, H., Denjean, C., Hartmann, S., Schneider, J., Schmidt, S., Ebert, M., and Stratmann, F.: Laboratorygenerated mixtures of mineral dust particles with biological substances: characterization of the particle mixing state and immersion freezing behavior, Atmos. Chem. Phys., 16, 5531-5543, https://doi.org/10.5194/acp-16-5531-2016, 2016.

Aumiller Jr., W. M., Uchida M., and Douglas T.: Protein cage assembly across multiple length scales, Chem. Soc. Rev., 47, 3433 3469, https://doi.org/10.1039/c7cs00818j, 2018.

Atkinson, J. D., Murray, B. J., Woodhouse, M. T., Whale, T. F., Baustian, K. J., Carslaw, K. S., Dobbie, S., O’Sullivan, D., and Malkin, T. L.: The importance of feldspar for ice nucleation by mineral dust in mixed-phase clouds, Nature, 498, 355-358, https://doi.org/10.1038/nature12278, 2013.

Bergeron, T.: Über die dreidimensional verknüpfende Wetteranalyse, Geophys. Norv., 5, 1-111, 1928.

Bigg, E. K.: Ice nucleus concentrations in remote areas, J. Atmos. Sci., 30, 1153-1157, https://doi.org/10.1175/15200469(1973)030<1153:INCIRA > 2.0.CO;2, 1973.

Bradford, M. M.: A rapid and sensitive method for the quantitation of microgram quantities of protein utilizing the principle of protein-dye binding, Anal. Biochem., 72, 248-254, https://doi.org/10.1016/0003-2697(76)90527-3, 1976. 
Budke, C. and Koop, T.: BINARY: an optical freezing array for assessing temperature and time dependence of heterogeneous ice nucleation, Atmos. Meas. Tech., 8, 689-703, https://doi.org/10.5194/amt-8-689-2015, 2015.

Burrows, S. M., Hoose, C., Pöschl, U., and Lawrence, M. G.: Ice nuclei in marine air: biogenic particles or dust?, Atmos. Chem. Phys., 13, 245-267, https://doi.org/10.5194/acp-13-2452013, 2013.

Conen, F., Morris, C. E., Leifeld, J., Yakutin, M. V., and Alewell, C.: Biological residues define the ice nucleation properties of soil dust, Atmos. Chem. Phys., 11, 9643-9648, https://doi.org/10.5194/acp-11-9643-2011, 2011.

Conrad, P., Ewing, G. E., Karlinsey, R. L., and Sadtchenko, V.: Ice nucleation on $\mathrm{BaF}_{2}(111)$, J. Chem. Phys., 122, 064709, https://doi.org/10.1063/1.1844393, 2005.

Crawford, I., Bower, K. N., Choularton, T. W., Dearden, C., Crosier, J., Westbrook, C., Capes, G., Coe, H., Connolly, P. J., Dorsey, J. R., Gallagher, M. W., Williams, P., Trembath, J., Cui, Z., and Blyth, A.: Ice formation and development in aged, wintertime cumulus over the UK: observations and modelling, Atmos. Chem. Phys., 12, 4963-4985, https://doi.org/10.5194/acp12-4963-2012, 2012.

Crichton, R. R. and Bryce, C. F. A.: Subunit interactions in horse spleen apoferritin - dissociation by extremes of $\mathrm{pH}$, Biochem. J., 133, 289-299, https://doi.org/10.1042/bj1330289, 1973.

Dalgleish, D. G. and Corredig, M.: The structure of the casein micelle of milk and its changes during processing, Annu. Rev. Food Sci. Technol., 3, 449-467, https://doi.org/10.1146/annurev-food022811-101214, 2012.

David, R. O., Cascajo-Castresana, M., Brennan, K. P., Rösch, M., Els, N., Werz, J., Weichlinger, V., Boynton, L. S., Bogler, S., Borduas-Dedekind, N., Marcolli, C., and Kanji, Z. A.: Development of the DRoplet Ice Nuclei Counter Zurich (DRINCZ): validation and application to field-collected snow samples, Atmos. Meas. Tech., 12, 6865-6888, https://doi.org/10.5194/amt12-6865-2019, 2019.

de Boer, G., Hashino, T., and Tripoli, G. J.: Ice nucleation through immersion freezing in mixed-phase stratiform clouds: Theory and numerical simulations, Atmos. Res., 96, 315-324, https://doi.org/10.1016/j.atmosres.2009.09.012, 2010.

DeMott, P. J. and Prenni, A. J.: New Directions: Need for defining the numbers and sources of biological aerosols acting as ice nuclei, Atmos. Environ., 44, 1944-1945, https://doi.org/10.1016/j.atmosenv.2010.02.032, 2010.

DeMott, P. J., Prenni, A. J., Liu, X., Kreidenweis, S. M., Petters, M. D., Twohy, C. H., Richardson, M. S., Eidhammer, T., and Rogers, D. C.: Predicting global atmospheric ice nuclei distributions and their impacts on climate, P. Natl. Acad. Sci. USA, 107, 1121711222, https://doi.org/10.1073/pnas.0910818107, 2010.

DeMott, P. J., Hill T. C. J., McCluskey C. S., Prather, K. A., Collins, D. B., Sullivan, R. C., Ruppel, M. J., Mason, R. H., Irish, V. E., Lee, T., Hwang, C. Y., Rhee, T. S., Snider, J. R., McMeeking, G. R., Dhaniyala, S., Lewis, E. R., Wentzell, J. J. B., Abbatt, J., Lee, C., Sultana, C. M., Ault, A. P., Axson, J. L., Diaz Martinez M., Venero, I., Santos-Figueroa, G., Stokes, M. D., Deane, G. B., Mayol-Bracero, O. L., Grassian, V. H., Bertram, T. H., Bertram, A. K., Moffett, B. F., and Franc, G. D.: Sea spray aerosol as a unique source of ice nu- cleating particles, P. Natl. Acad. Sci. USA, 113, 5797-5803, https://doi.org/10.1073/pnas.1514034112, 2016.

Després, V. R., Huffman, J. A., Burrows, S. M., Hoose, C., Safatov, A., Buryak, G., Fröhlich-Nowoisky, J., Elbert, W., Andreae, M. O., Pöschl, U., and Jaenicke, R.: Primary biological aerosol particles in the atmosphere: a review, Tellus B, 64, 15598 , https://doi.org/10.3402/tellusb.v64i0.15598, 2012.

Diehl, K., Quick, C., Matthias-Maser, S., Mitra, S. K., and Jaenicke, R.: The ice nucleating ability of pollen - Part I: Laboratory studies in deposition and condensation freezing modes, Atmos. Res., 58, 75-87, https://doi.org/10.1016/S0169-8095(01)000916, 2001

Du, R., Du, P., Lu, Z., Ren, W., Liang, Z., Qin, S., Li, Z., Wang, Y., and Fu, P.: Evidence for a missing source of efficient ice nuclei, Sci. Rep.-UK, 7, 39673, https://doi.org/10.1038/srep39673, 2017.

Eickhoff, L., Dreischmeier, K., Zipori, A., Sirotinskaya, V., Adar, C., Reicher, N., Braslavsky, I., Rudich, Y., and Koop, T.: Contrasting behavior of antifreeze proteins: Ice growth inhibitors and ice nucleation promoters, J. Phys. Chem. Lett., 10, 966-972, https://doi.org/10.1021/acs.jpclett.8b03719, 2019.

Eleta-Lopez, A. and Calò, A.: Key factors of scanning a plant virus with AFM in air and aqueous solution, Microsc. Res. Techniq., 80, 18-29, https://doi.org/10.1002/jemt.22741, 2017.

Engelstaedter, S., Tegen, I., and Washington, R.: North African dust emissions and transport, Earth-Sci. Rev., 79, 73-100, https://doi.org/10.1016/j.earscirev.2006.06.004, 2006.

Failor, K. C., Schmale III, D. G., Vinatzer, B. A., and Monteil, C. L.: Ice nucleation active bacteria in precipitation are genetically diverse and nucleate ice by employing different mechanisms, ISME J., 11, 2740-2753, https://doi.org/10.1038/ismej.2017.124, 2017.

Felgitsch, L., Baloh, P., Burkart, J., Mayr, M., Momken, M. E., Seifried, T. M., Winkler, P., Schmale III, D. G., and Grothe, H.: Birch leaves and branches as a source of icenucleating macromolecules, Atmos. Chem. Phys., 18, 1606316079, https://doi.org/10.5194/acp-18-16063-2018, 2018.

Field, P. R., Lawson, R. P., Brown, P. R. A., Lloyd, G., Westbrook, C., Moisseev, D., Miltenberger, A., Nenes, A., Blyth, A., Choularton, T., Connolly, P., Buehl, J., Crosier, J., Cui, Z., Dearden, C., DeMott, P., Flossman, A., Heymsfield, A., Huang, Y., Kalesse, H., Kanji, Z. A., Korolev, A., Kirchgaessner,A., Lasher-Trapp, S., Leisner, T., McFarquhar, G., Phillips, V., Stith, J., and Sullivan, S.: Secondary ice production: current state of the science and recommendations for the future, Meteor. Mon., 58, 7.1-7.20, https://doi.org/10.1175/AMSMONOGRAPHS-D16-0014.1, 2017.

Fillhart, R. C., Bachand, G. D., and Castello, J. D.: Airborne transmission of tomato mosaic Tobamovirus and its occurrence in red spruce in the northeastern United States, Can. J. Forest Res., 27, 1176-1181, https://doi.org/10.1139/x97-035, 1997.

Findeisen, W.: Kolloid-meteorologische Vorgänge bei Niederschlagsbildung, Meteorol. Z., 55, 121-133, 1938 (translated and edited by: Volken, E., Giesche, A. M., and Brönnimann, S.: Colloidal meteorological processes in the formation of precipitation, Meteorol. Z., 24, https://doi.org/10.1127/metz/2015/0675, 2015)

Fröhlich-Nowoisky, J., Hill, T. C. J., Pummer, B. G., Yordanova, P., Franc, G. D., and Pöschl, U.: Ice nucleation activity in the 
widespread soil fungus Mortierella alpina, Biogeosciences, 12, 1057-1071, https://doi.org/10.5194/bg-12-1057-2015, 2015.

Garnham, C. P., Campbell, R. L., Walker, V. K., and Davies, P. L.: Novel dimeric $\beta$-helical model of an ice nucleation protein with bridged active sites, BMC Struct. Biol., 11, 36, https://doi.org/10.1186/1472-6807-11-36, 2011.

Ge, P. and Zhou, Z. H.: Hydrogen-bonding networks and RNA bases revealed by cryo electron microscopy suggest a triggering mechanism for calcium switches, P. Natl. Acad. Sci. USA, 108, 9637-9642, https://doi.org/10.1073/pnas.1018104108, 2011.

Gerl, M. and Jaenicke, R.: Assembly of apoferritin from horse spleen: comparison of the protein in its native and reassembled state, Biol. Chem. H.-S., 368, 387-396, https://doi.org/10.1515/bchm3.1987.368.1.387, 1987.

Gerl, M., Jaenicke, R., Smith, J. M. A., and Harrison, P. M:. Self-assembly of apoferritin from horse spleen after reversible chemical modification with 2,3-dimethylmaleic anhydride, Biochemistry, 27, 4089-4096, https://doi.org/10.1021/bi00411a027, 1988.

Ghirlando, R., Mutskova, R., and Schwartz, C.: Enrichment and characterization of ferritin for nanomaterial applications, Nanotechnology, 27, 045102, https://doi.org/10.1088/09574484/27/4/045102, 2016.

Glatz, B. and Sarupria, S.: The surface charge distribution affects the ice nucleating efficiency of silver iodide, J. Chem. Phys., 145, 211924, https://doi.org/10.1063/1.4966018, 2016.

Glatz, B. and Sarupria, S.: Heterogeneous ice nucleation: Interplay of surface properties and their impact on water orientations, Langmuir, 34, 1190-1198, https://doi.org/10.1021/acs.langmuir.7b02859, 2018.

Ginoux, P., Prospero, J. M., Gill, T. E., Hsu, N. C., and Zhao, M.: Global-scale attribution of anthropogenic and natural dust sources and their emission rates based on MODIS Deep Blue aerosol products, Rev. Geophys., 50, RG3005, https://doi.org/10.1029/2012rg000388, 2012

Govindarajan, A. G. and Lindow, S. E.: Size of bacterial ice-nucleation sites measured in situ by radiation inactivation analysis, P. Natl. Acad. Sci. USA, 85, 1334-1338, https://doi.org/10.1073/pnas.85.5.1334, 1988.

Graether, S. P. and Jia, Z.: Modeling Pseudomonas syringae icenucleation protein as a $\beta$-helical protein, Biophys. J., 80, 1169 1173, https://doi.org/10.1016/S0006-3495(01)76093-6, 2001.

Haga, D. I., Iannone, R., Wheeler, M. J., Mason, R., Polishchuk, E. A., Fetch Jr., T., van der Kamp, B. J., McKendry, I. G., and Bertram, A. K.: Ice nucleation properties of rust and bunt fungal spores and their transport to high altitudes, where they can cause heterogeneous freezing. J. Geophys. Res.-Atmos. 118, 7260 7272, https://doi.org/10.1002/jgrd.50556, 2013.

Haga, D. I., Burrows, S. M., Iannone, R., Wheeler, M. J., Mason, R. H., Chen, J., Polishchuk, E. A., Pöschl, U., and Bertram, A. K.: Ice nucleation by fungal spores from the classes Agaricomycetes, Ustilaginomycetes, and Eurotiomycetes, and the effect on the atmospheric transport of these spores, Atmos. Chem. Phys., 14, 8611-8630, https://doi.org/10.5194/acp-14-8611-2014, 2014.

Hallett, J. and Mossop, S. C.: Production of secondary ice particles during the riming process, Nature, 249, 26-28, https://doi.org/10.1038/249026a0, 1974.

Häusler, T., Witek, L., Felgitsch, L., Hitzenberger, R., and Grothe, H.: Freezing on a chip - A new approach to determine heteroge- neous ice nucleation of micrometer-sized water droplets, Atmosphere, 9, 140, https://doi.org/10.3390/atmos9040140, 2018.

Hempstead, P. D., Yewdall, S. J., Fernie, A. R., Lawson, D. M., Artymiuk, P. J., Rice, D. W., Ford, G. C., and Harrison, P. M.: Comparison of the three-dimensional structures of recombinant human $\mathrm{H}$ and horse $\mathrm{L}$ ferritins at high resolution, J. Mol. Biol., 268, 424-448, https://doi.org/10.1006/jmbi.1997.0970, 1997.

Hill, T. C. J., Moffett, B. F., DeMott, P. J., Georgakopoulos, D. G., Stump, W. L., and Franc, G. D.: Measurement of ice nucleation-active bacteria on plants and in precipitation by quantitative PCR, Appl. Environ. Microb., 80, 1256-1267, https://doi.org/10.1128/AEM.02967-13, 2014.

Hill, T. C. J., DeMott, P. J., Tobo, Y., Fröhlich-Nowoisky, J., Moffett, B. F., Franc, G. D., and Kreidenweis, S. M.: Sources of organic ice nucleating particles in soils, Atmos. Chem. Phys., 16, 7195-7211, https://doi.org/10.5194/acp-16-7195-2016, 2016.

Hirano, S. S. and Upper, C. D.: Bacteria in the leaf ecosystem with emphasis on Pseudomonas syringae - a pathogen, ice nucleus, and epiphyte, Microbiol. Mol. Biol. R., 64, 624-653, https://doi.org/10.1128/MMBR.64.3.624-653.2000, 2000.

Hiranuma, N., Möhler, O., Yamashita, K., Tajiri, T., Saito, A., Kiselev, A., Hoffmann, N., Hoose, C., Jantsch, E., Koop, T., and Murakami, M.: Ice nucleation by cellulose and its potential contribution to ice formation in clouds, Nat. Geosci., 8, 273-277, https://doi.org/10.1038/ngeo2374, 2015a.

Hiranuma, N., Augustin-Bauditz, S., Bingemer, H., Budke, C., Curtius, J., Danielczok, A., Diehl, K., Dreischmeier, K., Ebert, M., Frank, F., Hoffmann, N., Kandler, K., Kiselev, A., Koop, T., Leisner, T., Möhler, O., Nillius, B., Peckhaus, A., Rose, D., Weinbruch, S., Wex, H., Boose, Y., DeMott, P. J., Hader, J. D., Hill, T. C. J., Kanji, Z. A., Kulkarni, G., Levin, E. J. T., McCluskey, C. S., Murakami, M., Murray, B. J., Niedermeier, D., Petters, M. D., O’Sullivan, D., Saito, A., Schill, G. P., Tajiri, T., Tolbert, M. A., Welti, A., Whale, T. F., Wright, T. P., and Yamashita, K.: A comprehensive laboratory study on the immersion freezing behavior of illite NX particles: a comparison of 17 ice nucleation measurement techniques, Atmos. Chem. Phys., 15, 2489-2518, https://doi.org/10.5194/acp-15-2489-2015, 2015b.

Hoose, C. and Möhler, O.: Heterogeneous ice nucleation on atmospheric aerosols: a review of results from laboratory experiments, Atmos. Chem. Phys., 12, 9817-9854, https://doi.org/10.5194/acp-12-9817-2012, 2012.

$\mathrm{Hu}, \mathrm{X} . \mathrm{L}$. and Michaelides, A.: Ice formation on kaolinite: Lattice match or amphoterism?, Surf. Sci., 601, 5378-5381, https://doi.org/10.1016/j.susc.2007.09.012, 2007.

Hudait, A., Odendahl, N., Qiu, Y., Paesani, F., and Molinero, V.: Icenucleating and antifreeze proteins recognize ice through a diversity of anchored clathrate and ice-like motifs, J. Am. Chem. Soc., 140, 4905-4912, https://doi.org/10.1021/jacs.8b01246, 2018.

Huffman, J. A., Prenni, A. J., DeMott, P. J., Pöhlker, C., Mason, R. H., Robinson, N. H., Fröhlich-Nowoisky, J., Tobo, Y., Després, V. R., Garcia, E., Gochis, D. J., Harris, E., MüllerGermann, I., Ruzene, C., Schmer, B., Sinha, B., Day, D. A., Andreae, M. O., Jimenez, J. L., Gallagher, M., Kreidenweis, S. M., Bertram, A. K., and Pöschl, U.: High concentrations of biological aerosol particles and ice nuclei during and after rain, Atmos. Chem. Phys., 13, 6151-6164, https://doi.org/10.5194/acp13-6151-2013, 2013. 
Huntington, J. A. and Stein, P. E.: Structure and properties of ovalbumin, J. Chromatogr. B, 756, 189-198, https://doi.org/10.1016/S0378-4347(01)00108-6, 2001.

Kajava, A. V. and Lindow, S. E.: A model of the three-dimensional structure of ice nucleation proteins, J. Mol. Biol. 232, 709-717, https://doi.org/10.1006/jmbi.1993.1424, 1993.

Kanji, Z. A., Ladino, L. A., Wex, H., Boose, Y., BurkertKohn, M., Cziczo, D. J., and Krämer, M.: Overview of ice nucleating particles, Meteor. Mon., 58, 1.1-1.33, https://doi.org/10.1175/AMSMONOGRAPHS-D-16-0006.1, 2017.

Kaufmann, L., Marcolli, C., Luo, B., and Peter, T.: Refreeze experiments with water droplets containing different types of ice nuclei interpreted by classical nucleation theory, Atmos. Chem. Phys., 17, 3525-3552, https://doi.org/10.5194/acp-173525-2017, 2017.

Kieft, T. L.: Ice nucleation activity in lichens, Appl. Environ. Microbiol., 54, 1678-1681, 1988.

Kieft, T. L. and Ahmadjian, V.: Biological ice nucleation activity in lichen mycobionts and photobionts, Lichenologist, 21, 355-362, https://doi.org/10.1017/S0024282989000599, 1989.

Kieft, T. L. and Ruscetti, T.: Characterization of biological ice nuclei from a lichen, J. Bacteriol., 172, 3519-3523, https://doi.org/10.1128/jb.172.6.3519-3523.1990, 1990.

Kieft, T. L. and Ruscetti T.: Molecular sizes of lichen ice nucleation sites determined by gamma radiation inactivation analysis, Cryobiology, 29, 407-413, https://doi.org/10.1016/00112240(92)90042-Z, 1992.

Kim H. K., Orser, C., Lindow, S. E., and Sands, D. C.: Xanthomonas campestris pv. translucens strains active in ice nucleation, Plant Dis., 71, 994-997, https://doi.org/10.1094/PD-71-0994, 1987.

Kim, M., Rho, Y., Jin, K. S., Ahn, B., Jung, S., Kim, H., and Ree, M.: pH-dependent structures of ferritin and apoferritin in solution: Disassembly and reassembly, Biomacromolecules, 12, 1629-1640, https://doi.org/10.1021/bm200026v, 2011.

Knopf, D. A., Alpert, P. A., and Wang, B.: The role of organic aerosol in atmospheric ice nucleation: A review, ACS Earth Space Chem., 2, 168-202, https://doi.org/10.1021/acsearthspacechem.7b00120, 2018.

Korolev, A.: Limitations of the Wegener-Bergeron-Findeisen mechanism in the evolution of mixed-phase clouds, J. Atmos. Sci., 64, 3372-3375, https://doi.org/10.1175/JAS4035.1, 2007.

Korolev, A. and Field, P. R.: The effect of dynamics on mixed-phase clouds: Theoretical considerations, J. Atmos. Sci., 65, 66-86, https://doi.org/10.1175/2007JAS2355.1, 2008.

Kudr, J., Nejdl, L., Skalickova, S., Zurek, M., Milosavlijevic, V., Kensova, R., Ruttkay-Nedecky, B., Kopel, P., Hynek, D., Novotna, M., Adam, V., and Kizek, R.: Use of nucleic acids anchor system to reveal apoferritin modification by cadmium telluride nanoparticles, J. Mater. Chem. B, 3, 2109-2118, https://doi.org/10.1039/c4tb01336k, 2015.

Kumar, A., Marcolli, C., and Peter, T.: Ice nucleation activity of silicates and aluminosilicates in pure water and aqueous solutions - Part 2: Quartz and amorphous silica, Atmos. Chem. Phys., 19, 6035-6058, https://doi.org/10.5194/acp-19-6035-2019, 2019a.

Kumar, A., Marcolli, C., and Peter, T.: Ice nucleation activity of silicates and aluminosilicates in pure water and aqueous solutions - Part 3: Aluminosilicates, Atmos. Chem. Phys., 19, 6059-6084, https://doi.org/10.5194/acp-19-6059-2019, 2019b.
Ladino, L. A., Yakobi-Hancock, J. D., Kilthau, W. P., Mason, R. H., Si, M., Li, J., Miller, L. A., Schiller, C. L., Huffman, J. A., Aller, J. Y., Knopf, D. A., Bertram, A. K., and Abbatt, J. P. D.: Addressing the ice nucleating abilities of marine aerosol: A combination of deposition mode laboratory and field measurements, Atmos. Environ., 132, 1-10, https://doi.org/10.1016/j.atmosenv.2016.02.028, 2016.

Lauber, A., Kiselev, A., Pander, T., Handmann, P., and Leisner, T.: Secondary ice formation during freezing of levitated droplets, J. Atmos. Sci., 75, 2815-2826, https://doi.org/10.1175/JAS-D180052.1, 2018.

Lee, J. H., Park, A. K., Do, H., Park, K. S., Moh, S. H., Chi, Y. M., and Kim, H. J: Structural basis for antifreeze activity of icebinding protein from Arctic yeast, J. Biol. Chem., 287, 1146011468, https://doi.org/10.1074/jbc.M111.331835, 2012.

Levin, Z. and Yankofsky, S. A.: Contact versus immersion freezing of freely suspended droplets by bacterial ice nuclei, J. Clim. Appl. Meteorol., 22, 1964-1966, https://doi.org/10.1175/15200450(1983)022<1964:CVIFOF>2.0.CO;2, 1983.

Linder, M. C., Kakavandi, H. R., Miller, P., Wirth, P. L., and Nagel, G. M.: Dissociation of ferritins, Arch. Biochem. Biophys., 269, 485-496, https://doi.org/10.1016/0003-9861(89)90132-X, 1989.

Lindow, S. E.: The role of bacterial ice nucleation in frost injury to plants, Ann. Rev. Phytopathol., 21, 363-384, https://doi.org/10.1146/annurev.py.21.090183.002051, 1983.

Lindow, S. E., Arny, D. C., and Upper, C. D.: Erwinia herbicola: a bacterial ice nucleus active in increasing frost injury to corn, Phytopathology, 68, 523-527, https://doi.org/10.1094/Phyto-68523, 1978.

Lindow, S. E., Lahue, E., Govindarajan, A. G., Panopoulos, N. J., and Gies, D.: Localization of ice nucleation activity and the iceC gene product in Pseudomonas syringae and Escherichia coli, Mol. Plant. Microbe. In., 2, 262-272, https://doi.org/10.1094/Mpmi-2-262, 1989.

Ling, M. L., Wex, H., Grawe, S., Jakobsson, J., Löndahl, J., Hartmann, S., Finster, K., Boesen, T., and Šantl-Temkiv, T.: Effects of ice nucleation protein repeat number and oligomerization level on ice nucleation activity, J. Geophys. Res.-Atmos., 123, 18021810, https://doi.org/10.1002/2017JD027307, 2018.

Lucey, J. A. and Horne, D. S.: Perspectives on casein interactions, Int. Dairy J., 85, 56-65, https://doi.org/10.1016/j.idairyj.2018.04.010, 2018.

Maki, L. R., Galyan, E. L., Chang-Chien, M.-M., and Caldwell, D. R.: Ice nucleation induced by Pseudomonas syringae, Appl. Microbiol., 28, 456-459, 1974.

Manciu M. and Ruckenstein, E.: Long range interactions between apoferritin molecules, Langmuir, 18, 8910-8918, https://doi.org/10.1021/la026126m, 2002.

Marcolli, C.: Protein aggregates nucleate ice: the example of apoferritin, https://doi.org/10.3929/ethz-b-000391914, 2020.

Marcolli, C., Nagare, B., Welti, A., and Lohmann, U.: Ice nucleation efficiency of AgI: review and new insights, Atmos. Chem. Phys., 16, 8915-8937, https://doi.org/10.5194/acp-168915-2016, 2016.

Massover, W. H.: The ultrastructure of ferritin macromolecules, III. Mineralized iron in ferritin is attached to the protein shell, J. Mol. Biol., 123, 721-726, https://doi.org/10.1016/00222836(78)90218-8, 1978. 
Massover, W. H.: Ultrastructural evidence for the dissociation of free subunits from ferritin upon dilution, Biochem. Bioph, Res. Co., 96, 1427-1433, https://doi.org/10.1016/0006291X(80)90110-2, 1980.

Massover, W. H.: Ultrastructure of ferritin and apoferritin: a review, Micron, 24, 389-437, https://doi.org/10.1016/09684328(93)90005-L, 1993.

Matus, A. V. and L'Ecuyer, T. S.: The role of cloud phase in Earth's radiation budget, J. Geophys. Res.-Atmos., 122, 2559 2578, https://doi.org/10.1002/2016JD025951, 2017.

May, C. A., Grady, J. K,, Laue, T. M., Poli, M., Arosio, P., and Chasteen, N. D.: The sedimentation properties of ferritins. New insights and analysis of methods of nanoparticle preparation, Biochim. Biophys, Acta, 1800, 858-870, https://doi.org/10.1016/j.bbagen.2010.03.012, 2010.

Moffett, B. F., Getti, G., Henderson-Begg, S. K., and Hill, T. C. J.: Ubiquity of ice nucleation in lichen - possible atmospheric implications, Lindbergia 38, 39-43, 2015.

Möhler, O., DeMott, P. J., Vali, G., and Levin, Z.: Microbiology and atmospheric processes: the role of biological particles in cloud physics, Biogeosciences, 4, 1059-1071, https://doi.org/10.5194/bg-4-1059-2007, 2007

Morris, C. E., Sands, D. C., Glaux, C., Samsatly, J., Asaad, S., Moukahel, A. R., Gonçalves, F. L. T., and Bigg, E. K.: Urediospores of rust fungi are ice nucleation active at $>-10^{\circ} \mathrm{C}$ and harbor ice nucleation active bacteria, Atmos. Chem. Phys., 13, 4223-4233, https://doi.org/10.5194/acp-13-4223-2013, $2013 \mathrm{a}$.

Morris V. K., Kwan, A. H., and Sunde, M.: Analysis of the structure and conformational states of DewA gives insight into the assembly of the fungal hydrophobins, J. Mol. Biol., 425, 244-256, https://doi.org/10.1016/j.jmb.2012.10.021, 2013b.

Mortazavi, R., Hayes, C. T, and Ariya, P. A.: Ice nucleation activity of bacteria isolated from snow compared with organic and inorganic substrates, Environ. Chem., 5, 373-381, https://doi.org/10.1071/EN08055, 2008.

Mülmenstädt, J., Sourdeval, O., Delanoë, J., and Quaas, J.: Frequency of occurrence of rain from liquid-, mixed-, and ice-phase clouds derived from A-Train satellite retrievals, Geophys. Res. Lett., 42, 6502-6509, https://doi.org/10.1002/2015GL064604, 2015.

Murray, B. J., O'Sullivan, D., Atkinson, J. D., and Webb, M. E.: Ice nucleation by particles immersed in supercooled cloud droplets, Chem. Soc. Rev., 41, 6519-6554, https://doi.org/10.1039/C2CS35200A, 2012.

Oades, J. M.: The role of biology in the formation, stabilization and degradation of soil structure, Geoderma, 56, 377-400, https://doi.org/10.1016/0016-7061(93)90123-3, 1993.

O'Sullivan, D., Murray, B. J., Malkin, T. L., Whale, T. F., Umo, N. S., Atkinson, J. D., Price, H. C., Baustian, K. J., Browse, J., and Webb, M. E.: Ice nucleation by fertile soil dusts: relative importance of mineral and biogenic components, Atmos. Chem. Phys., 14, 1853-1867, https://doi.org/10.5194/acp-141853-2014, 2014.

Ozeki, T., Verma, V., Uppalapati, M., Suzuki, Y., Nakamura, M., Catchmark, J. M., and Hancock, W. O.: Surfacebound casein modulates the adsorption and activity of kinesin on $\mathrm{SiO}_{2}$ surfaces, Biophys. J., 96, 3305-3318, https://doi.org/10.1016/j.bpj.2008.12.3960, 2009.
Pandey, R., Usui, K., Livingstone, R. A., Fischer, S. A., Pfaendtner, J., Backus, E. H. G., Nagata, Y., Fröhlich-Nowoisky, J., Schmüser, L., Mauri, S., Scheel, J. F., Knopf, D. A., Pöschl, U., Bonn, M., and Weidner, T.: Ice-nucleating bacteria control the order and dynamics of interfacial water, Sci. Adv., 2, e1501630, https://doi.org/10.1126/sciadv.1501630, 2016.

Pedevilla, P., Fitzner, M., and Michaelides, A.: What makes a good descriptor for heterogeneous ice nucleation on OH-patterned surfaces, Phys. Rev. B, 96, 115441, https://doi.org/10.1103/PhysRevB.96.115441, 2017.

Petsev, D. N. and Vekilov, P. G.: Evidence for nonDLVO hydration interactions in solutions of the protein apoferritin, Phys. Rev. Lett., 84, 1339-1342, https://doi.org/10.1103/PhysRevLett.84.1339, 2000.

Petsev, D. N., Thomas, B. R., Yau, S.-T., and Vekilov, P. G.: Interactions and aggregation of apoferritin molecules in solution: effects of added electrolytes, Biophys. J., 78, 2060-2069, https://doi.org/10.1016/S0006-3495(00)76753-1, 2000.

Petsev, D. N., Thomas, B. R., Yau, S.-T., Tsekova, D., Nanev, C., Wilson, W. W., and Vekilov, P. G.: Temperatureindependent solubility and interactions between apoferritin monomers and dimers in solution, J. Cryst. Growth, 232, 21-29, https://doi.org/10.1016/S0022-0248(01)01095-8, 2001.

Polen, M., Lawlis, E., and Sullivan, R. C.: The unstable ice nucleation properties of Snomax ${ }^{\circledR}$ bacterial particles, J. Geophys. Res.-Atmos., 121, 11666-11678, https://doi.org/10.1002/2016JD025251, 2016.

Ponder, M. A., Gilmour, S. J., Bergholz, P. W., Mindock, C. A., Hollingsworth, R., Thomashow, M. F., and Tiedje, J. M.: Characterization of potential stress responses in ancient Siberian permafrost psychroactive bacteria, FEMS Microbiol. Ecol., 53, 103115, https://doi.org/10.1016/j.femsec.2004.12.003, 2005.

Popovitz-Biro, R., Wang, J. L., Majewski, J., Shavit, E., Leiserowitz, L., and Lahav, M.: Induced freezing of supercooled water into ice by self-assembled crystalline monolayers of amphiphilic alcohols at the air-water interface, J. Am. Chem. Soc., 116, 1179-1191, https://doi.org/10.1021/ja00083a003, 1994.

Pouleur, S., Richard, C., Martin, J.-G., and Antoun, H.: Ice Nucleation Activity in Fusarium acuminatum and Fusarium avenaceum, Appl. Environ. Microb., 58, 2960-2964, 1992.

Pratt, K. A., DeMott, P. J., French, J. R., Wang, Z.,Westphal, D. L., Heymsfield, A. J., Twohy, C. H., Prenni, A. J., and Prather, K. A.: In situ detection of biological particles in cloud ice-crystals, Nat. Geosci., 2, 398-401, https://doi.org/10.1038/NGEO521, 2009.

Prenni, A. J., Tobo, Y., Garcia, E., DeMott, P. J., Huffman, J. A., McCluskey, C. S., Kreidenweis, S. M., Prenni, J. E., Pöhlker, C., and Pöschl, U.: The impact of rain on ice nuclei populations at a forested site in Colorado, Geophys. Res. Lett., 40, 227-231, https://doi.org/10.1029/2012gl053953, 2013.

Prospero, J. M., Ginoux, P., Torres, O., Nicholson, S. E., and Gill, T. E.: Environmental characterization of global sources of atmospheric soil dust identified with the nimbus 7 total ozone mapping spectrometer (TOMS) absorbing aerosol product, Rev. Geophys., 40, 1002, https://doi.org/10.1029/2000RG000095, 2002.

Pummer, B. G., Bauer, H., Bernardi, J., Bleicher, S., and Grothe, H.: Suspendable macromolecules are responsible for ice nucleation activity of birch and conifer pollen, Atmos. Chem. Phys., 12, 2541-2550, https://doi.org/10.5194/acp-12-2541-2012, 2012. 
Pummer, B. G., Atanasova, L., Bauer, H., Bernardi, J., Druzhinina, I. S., Fröhlich-Nowoisky, J., and Grothe, H.: Spores of many common airborne fungi reveal no ice nucleation activity in oil immersion freezing experiments, Biogeosciences, 10, 80838091, https://doi.org/10.5194/bg-10-8083-2013, 2013.

Pummer, B. G., Budke, C., Augustin-Bauditz, S., Niedermeier, D., Felgitsch, L., Kampf, C. J., Huber, R. G., Liedl, K. R., Loerting, T., Moschen, T., Schauperl, M., Tollinger, M., Morris, C. E., Wex, H., Grothe, H., Pöschl, U., Koop, T., and Fröhlich-Nowoisky, J.: Ice nucleation by watersoluble macromolecules, Atmos. Chem. Phys., 15, 4077-4091, https://doi.org/10.5194/acp-15-4077-2015, 2015.

Qiu, Y., Odendahl, N., Hudait, A., Mason, R., Bertram, A. K., Paesani, F., DeMott, P. J., and Molinero, V.: Ice nucleation efficiency of hydroxylated organic surfaces is controlled by their structural fluctuations and mismatch to ice, J. Am. Chem. Soc., 139, 30523064, https://doi.org/10.1021/jacs.6b12210, 2017.

Qiu, Y., Hudait, A., and Molinero, V.: How size and aggregation of ice-binding proteins control their ice nucleation efficiency, J. Am. Chem. Soc., 141, 7439-7452, https://doi.org/10.1021/jacs.9b01854, 2019.

Rebouillat, S. and Ortega-Requena, S.: Potential applications of milk fractions and valorization of dairy by-products: A review of the state-of-the-art available data, outlining the innovation potential from a bigger data standpoint, J. Biomat. Nanobiotech., 6, 176-203, https://doi.org/10.4236/jbnb.2015.63018, 2015.

Richter, G. W. and Walker, G. F.: Reversible association of apoferritin molecules. Comparison of lightscattering and other data, Biochemistry, 6, 2871-2881, https://doi.org/10.1021/bi00861a031, 1967.

Rigg, Y. J., Alpert, P. A., and Knopf, D. A.: Immersion freezing of water and aqueous ammonium sulfate droplets initiated by humic-like substances as a function of water activity, Atmos. Chem. Phys., 13, 6603-6622, https://doi.org/10.5194/acp13-6603-2013, 2013.

Russo, C. J. and Passmore, L. A.: Ultrastable gold substrates for electron cryomicroscopy, Science, 346, 1377-1380, https://doi.org/10.1126/science.1259530, 2014.

Santambrogio, P., Levi, S., Arosio, P., Palagi, L., Vecchio, G., Lawson, D. M., Yewdall, S. J., Artymiuk, P. J., Harrison, P. M., Jappelli, R., and Cesareni, G.: Evidence that a salt bridge in the light chain contributes to the physical stability difference between heavy and light human ferritins, J. Biol. Chem., 287, 1407714083, 1992.

Sassen, K., DeMott, P. J., Prospero, J. M., and Poellot, M. R.: Saharan dust storms and indirect aerosol effects on clouds: CRYSTAL-FACE results, Geophys. Res. Lett., 30, 1633, https://doi.org/10.1029/2003GL017371, 2003.

Schmid, D., Pridmore, D., Capitani, G., Battistutta, R., Neeser, J.-R., and Jann, A.: Molecular organisation of the ice nucleation protein InaV from Pseudomonas syringae, FEBS Lett., 414, 590-594, https://doi.org/10.1016/S0014-5793(97)01079-X, 1997.

Schnell, R. C.: Ice nuclei produced by laboratory cultured marine phytoplankton, Geophys. Res. Lett., 2, 500-502, 1975.

Schnell, R. C. and Vali, G.: Biogenic ice nuclei: Part I. Terrestrial and marine sources, J. Atmos. Sci., 33, 1554-1564, https://doi.org/10.1175/15200469(1976)033<1554:BINPIT>2.0.CO;2, 1976.
Simoneit, B. R. T., Elias, V. O., Kobayashi, M., Kawamura, K., Rushdi, A. I., Medeiros, P. M., Rogge, W. F., and Didyk, B. M.: Sugars - dominant water-soluble organic compounds in soils and characterization as tracers in atmospheric particulate matter, Environ. Sci. Technol., 38, 5939-5949, https://doi.org/10.1021/es0403099, 2004.

Smith-Johannsen, H. and Drysdale, J. W.: Reversible dissociation of ferritin and its subunits in vitro, Biochim. Biophys. Acta, 194, 43-49, https://doi.org/10.1016/0005-2795(69)90177-9, 1969.

Stefanini, S., Cavallo, S., Wang, C.-Q., Tataseo, P., Vecchini, P, Giartosio, A., and Chiancone, E.: Thermal stability of horse spleen apoferritin and human recombinant $\mathrm{H}$ apoferritin, Arch. Biochem. Biophys., 325, 58-64, 10.1006/abbi.1996.0007, 1996.

Stein, P. E., Leslie, A. G. W., Finch, J. T., and Carrell, R. W.: Crystal structure of uncleaved ovalbumin at $1.95 \AA$ resolution, J. Mol. Biol., 221, 941-959, https://doi.org/10.1016/00222836(91)80185-W, 1991.

Steinke, I., Funk, R., Busse, J., Iturri, A., Kirchen, S., Leue, M., Möhler, O., Schwartz, T., Schnaiter, M., Sierau, B., Toprak, E., Ullrich, R., Ulrich, A., Hoose, C., and Leisner, T.: Ice nucleation activity of agricultural soil dust aerosols from Mongolia, Argentina, and Germany, J. Geophys. Res.-Atmos., 121, 1355913576, https://doi.org/10.1002/2016JD025160, 2016.

Stetefeld, J., McKenna, S. A., and Patel, T. R.: Dynamic light scattering: a practical guide and applications in biomedical sciences, Biophys. Rev., 8, 409-427, https://doi.org/10.1007/s12551-0160218-6, 2016.

Stopelli, E., Conen, F., Zimmermann, L., Alewell, C., and Morris, C. E.: Freezing nucleation apparatus puts new slant on study of biological ice nucleators in precipitation, Atmos. Meas. Tech., 7, 129-134, https://doi.org/10.5194/amt-7-129-2014, 2014.

Sunde, M., Pham, C. L. L., and Kwan, A. H.: Molecular characteristics and biological functions of surface-active and surfactant proteins, Annu. Rev. Biochem., 86, 585-608, https://doi.org/10.1146/annurev-biochem-061516-044847, 2017.

Swaisgood, H. E.: Review and update of casein chemistry, J. Dairy Sci., 76, 3054-3061, https://doi.org/10.3168/jds.S00220302(93)77645-6, 1993.

Tegen, I., Werner, M., Harrison, S. P., and Kohfeld, K. E.: Relative importance of climate and land use in determining present and future global soil dust emission, Geophys. Res. Lett., 31, L05105, https://doi.org/10.1029/2003GL019216, 2004.

Thomas, B. R., Carter, D., and Rosenberger, F.: Effect of microheterogeneity on horse spleen apoferritin crystallization, J. Cryst. Growth, 187, 499-510, https://doi.org/10.1016/S00220248(98)00033-5, 1998.

Tobo, Y.: An improved approach for measuring immersion freezing in large droplets over a wide temperature range, Sci. Rep.-UK, 6, 32930, https://doi.org/10.1038/srep32930, 2016.

Tobo, Y., Prenni, A. J., DeMott, P. J., Huffman, J. A., McCluskey, C. S., Tian, G., Pöhlker, C., Pöschl, U., and Kreidenweis, S. M.: Biological aerosol particles as a key determinant of ice nuclei populations in a forest ecosystem, J. Geophys. Res.-Atmos., 118, 10100-10110, https://doi.org/10.1002/jgrd.50801, 2013.

Tobo, Y., DeMott, P. J., Hill, T. C. J., Prenni, A. J., SwobodaColberg, N. G., Franc, G. D., and Kreidenweis, S. M.: Organic matter matters for ice nuclei of agricultural soil origin, Atmos. Chem. Phys., 14, 8521-8531, https://doi.org/10.5194/acp14-8521-2014, 2014. 
Tong, H.-J., Ouyang, B., Nikolovski, N., Lienhard, D. M., Pope, F. D., and Kalberer, M.: A new electrodynamic balance (EDB) design for low-temperature studies: application to immersion freezing of pollen extract bioaerosols, Atmos. Meas. Tech., 8, 11831195, https://doi.org/10.5194/amt-8-1183-2015, 2015.

Vali, G.: Interpretation of freezing nucleation experiments: singular and stochastic; sites and surfaces, Atmos. Chem. Phys., 14, 5271-5294, https://doi.org/10.5194/acp-14-5271-2014, 2014.

Vali, G.: Revisiting the differential freezing nucleus spectra derived from drop-freezing experiments: methods of calculation, applications, and confidence limits, Atmos. Meas. Tech., 12, 12191231, https://doi.org/10.5194/amt-12-1219-2019, 2019.

Vali, G. and Stansbury, E. J.: Time-dependent characteristics of the heterogeneous nucleation of ice, Can. J. Phys., 44, 477-502, https://doi.org/10.1139/p66-044, 1966.

Vali, G., Christensen, M., Fresh, R. W., Galyan, E. L., Maki, L. R., and Schnell, R. C.: Biogenic ice nuclei. Part II: Bacterial sources, J. Atmos. Sci., 33, 1565-1570, https://doi.org/10.1175/15200469(1976)033<1565:BINPIB >2.0.CO;2, 1976.

Vali, G., DeMott, P. J., Möhler, O., and Whale, T. F.: Technical Note: A proposal for ice nucleation terminology, Atmos. Chem. Phys., 15, 10263-10270, https://doi.org/10.5194/acp-15-102632015, 2015.

Valle-Delgado, J. J., Molina-Bolivar, J. A., Galisteo-González, F., Gálvez-Ruiz, M. J., Feiler, A., and Rutland, M. W.: Existence of hydration forces in the interaction between apoferritin molecules adsorbed on silica surfaces, Langmuir, 21, 95449554, https://doi.org/10.1021/la050825s, 2005.

von Blohn, N., Mitra, S. K., Diehl, K., and Borrmann, S.: The ice nucleating ability of pollen. Part III: New laboratory studies in immersion and contact freezing modes including more pollen types, Atmos. Res., 78, 182-189, https://doi.org/10.1016/j.atmosres.2005.03.008, 2005.

Wang, B. and Knopf, D. A.: Heterogeneous ice nucleation on particles composed of humic-like substances impacted by $\mathrm{O}_{3}$, J. Geophys. Res., 116, D03205, https://doi.org/10.1029/2010JD014964, 2011.

Wang, X., Sultana, C. M., Trueblood, J., Hill, T. C. J., Malfatti, F., Lee, C., Laskina, O., Moore, K. A., Beall, C. M., McCluskey, C. S., Cornwell, G. C., Zhou, Y., Cox, J. L., Pendergraft, M. A., Santander, M. V., Bertram, T. H., Cappa, C. D., Azam, F., DeMott, P. J., Grassian, V. H., and Prather, K. A.: Microbial control of sea spray aerosol composition: A tale of two blooms, ACS Cent. Sci., 1, 124-131, https://doi.org/10.1021/acscentsci.5b00148, 2015.

Wegener, A.: Thermodynamik der Atmosphäre, Barth, Leipzig, Germany, 1911.

Wessels, J. G. H.: Fungal hydrophobins: proteins that function at an interface, Trends Plant Sci., 1, 9-15, https://doi.org/10.1016/S1360-1385(96)80017-3, 1996.

Westbrook, C. D. and Illingworth, A. J.: The formation of ice in a long-lived supercooled layer cloud, Q. J. Roy. Meteor. Soc., 139, 2209-2221, https://doi.org/10.1002/qj.2096, 2013.

Wex, H., Augustin-Bauditz, S., Boose, Y., Budke, C., Curtius, J., Diehl, K., Dreyer, A., Frank, F., Hartmann, S., Hiranuma, N., Jantsch, E., Kanji, Z. A., Kiselev, A., Koop, T., Möhler, O., Niedermeier, D., Nillius, B., Rösch, M., Rose, D., Schmidt, C., Steinke, I., and Stratmann, F.: Intercomparing different devices for the investigation of ice nucleating particles using
Snomax ${ }^{\circledR}$ as test substance, Atmos. Chem. Phys., 15, 14631485, https://doi.org/10.5194/acp-15-1463-2015, 2015.

Wilson, T. W., Ladino, L. A., Alpert, P. A., Breckels, M. N., Brooks, I. M., Browse, J., Burrows, S. M., Carslaw, K. S., Huffman, J. A., Judd, C., Kilthau, W. P., Mason, R. H., McFiggans, G., Miller, L. A., Najera, J. J., Polishchuk, E., Rae, S., Schiller, C. L., Si, M., Temprado, J. V., Whale, T. F., Wong, J. P. S., Wurl, O., Yakobi-Hancock, J. D., Abbatt, J. P. D., Aller, J. Y., Bertram, A. K., Knopf, D. A., and Murray, B. J.: A marine biogenic source of atmospheric ice-nucleating particles, Nature, 525, 234-238, https://doi.org/10.1038/nature14986, 2015.

Wohlleben, W., Subkowski, T., Bollschweiler, C., von Vacano, B., Liu, Y., Schrepp, W., and Baus, U.: Recombinantly produced hydrophobins from fungal analogues as highly surface-active performance proteins, Eur. Biophys. J. Biophy., 39, 457-468, https://doi.org/10.1007/s00249-009-0430-4, 2010.

Wolber, P. K.: Bacterial ice nucleation, Adv. Microb. Physiol., 34, 203-237, https://doi.org/10.1016/S0065-2911(08)60030-2, 1993.

Yang, D., Matsubara, K., Yamaki, M., Ebina, S., and Nagayama, K.: Heterogeneities in ferritin dimers as characterized by gel-filtration, nuclear magnetic resonance, electrophoresis, transmission electron microscopy, and gene engineering techniques, Biochim. Biophys. Acta, 1206, 173-179, https://doi.org/10.1016/0167-4838(94)90205-4, 1994.

Yankofsky, S. A., Levin, Z., Bertold, T., and Sandlerman, N.: Some basic characteristics of bacterial freezing nuclei, J. Appl. Meteorol., 20, 1013-1019, https://doi.org/10.1175/15200450(1981)020<1013:SBCOBF>2.0.CO;2, 1981.

Yano, J.-I. and Phillips, V. T. J.: Ice-ice collisions: an ice multiplication process in atmospheric clouds, J. Atmos. Sci., 68, 322-333, https://doi.org/10.1175/2010JAS3607.1, 2011.

Yoshizawa, K., Mishima, Y., Park, S.-Y., Heddle, J. G., Tame, J. R. H., Iwahori, K., Kobayashi, M., and Yamashita, I.: Effect of Nterminal residues on the structural stability of recombinant horse L-chain apoferritin in an acidic environment, J. Biochem. 142, 707-713, https://doi.org/10.1093/jb/mvm187, 2007.

Zachariassen, K. E. and Kristiansen, E.: Ice nucleation and antinucleation in Nature, Cryobiol., 41, 257-279, https://doi.org/10.1006/cryo.2000.2289, 2000.

Zender, C. S., Miller, R. L., and Tegen, I.: Quantifying mineral dust mass budgets: Terminology, constraints, and current estimates, EOS T. AGU, 85, 509-512, https://doi.org/10.1029/2004EO480002, 2004.

Zeth, K., Hoiczyk, E., and Okuda, M.: Ferroxidase-mediated iron oxide biomineralization: Novel pathways to multifunctional nanoparticles, Trends Biochem. Sci, 41, 190-203, https://doi.org/10.1016/j.tibs.2015.11.011, 2016.

Zobrist, B., Koop, T., Luo, B. P., Marcolli, C., and Peter, T.: Heterogeneous ice nucleation rate coefficient of water droplets coated by a nonadecanol monolayer, J. Phys. Chem. C, 111, 2149-2155, https://doi.org/10.1021/jp066080w, 2007. 